\title{
FUNGSI PENGAWASAN DPRD DALAM MEWUJUDKAN TATA KELOLA PEMERINTAHAN YANG BAIK DI KOTA DEPOK PROVINSI JAWA BARAT
}

\author{
Oleh \\ Isay Wenda ${ }^{1}$, \\ Ermaya Surdinata ${ }^{2}$, M. Irwan Tahir ${ }^{3}$ \\ 1) Biro BPSDM Sekda Provinsi Papua \\ Program Magister Terapan Studi Pemerintahan Daerah Institut Pemerintahan Dalam Negeri \\ isaywenda16@gmail.com \\ ${ }^{2,3)}$ Institut Pemerintahan Dalam Negeri
}

\begin{abstract}
SUPERVISION FUNCTIONS OF DPRD IN REALIZING GOOD GOVERNANCE IN DEPOK CITY WEST JAVA PROVINCE
\end{abstract}

$T^{\mathrm{s}}$

is study aims to find out: (1) How the Supervisory Function of the DPRD in Realizing Good Governance in the City of Depok, West Java Province (2) What are the factors that hinder the PDRD in Supervision to Realize Good Governance in the City of Depok Province West Java. (3) How are the Efforts to Revitalize the Supervisory Function of the DPRD in Realizing Good Governance in Depok City, West Java Province

The results of this study indicate that: (1) In accordance with Article 82 of Law No. 22 of 2003. The supervision carried out includes administrative corrective actions such as the making of new regional regulations, termination of projects and programs. For field supervision, the Depok City DPRD also went to the work location to ensure that the work had been carried out in accordance with the Planning and Regulations. (2) The Barrier Factor in the Supervisory Function of the DPRD was that the Council was always busy dealing with the affairs of political parties, even though it was regulated in the Rules of Procedure that the duties of the Council were: should take precedence over other matters, but in reality the Council always puts political matters first. In addition, the public also criticized that members of the Regional House of Representatives were considered unprofessional, because the Regional House of Representatives had not been able to optimize the supervisory function, with indicators of budget absorption by the executive running almost without significant supervision. In fact, there are very frequent waves of protests from activists and students who are pro-democracy against regional people's representative institutions which are considered not optimal in running the regional government system. (3) In fact, in realizing good governance, each community must also participate in implementing good governance. So, what is meant by good governance is a form or form of responsibility that includes administrative authority, economic authority to political authority in order to regulate all regional social problems.

Keywords: DPRD supervision function, good governance 


\begin{abstract}
Abstrak
$\mathrm{P}$ enelitian ini bertujuan untuk mengetahui : (1) Bagaimana Fungsi Pengawasan Dprd Dalam Mewujudkan Tata Kelola Pemerintahan yang Baik Di Kota Depok Provinsi Jawa Barat (2) Faktor-Faktor Apa Saja yang Menghambat PDRD Dalam Pengawasan Untuk Mewujudkan Tata Kelola Pemerintahan yang Baik Di Kota Depok Provinsi Jawa Barat. (3) Bagaimana Upaya Revitalisasi Fungsi Pengawasan DPRD Dalam Mewujudkan Tata Kelola Pemerintahan yang Baik Di Kota Depok Provinsi Jawa Barat

Hasil penelitian ini menunjukkan bahwa: (1) Sesuai dengan Pasal 82 UU No. 22 Tahun 2003. Pengawasan yang dilakukan antara lain tindakan perbaikan secara Administrasi misalnya pembuatan Raperda Baru, Penghentian Proyek Maupun Program. Untuk pengawasan lapangan DPRD Kota Depok juga turun ke lokasi pekerjaan untuk memastikan pekerjaan sudah dilaksanakan sesuai dengan Perencanaan dan Peraturan (2) Faktor Penghambat dalam Fungsi Pengawasan DPRD adalah sehubungan Dewan selalu sibuk dalam mengurusi urusan partai politik, walaupun di atur dalam Tata Tertib bahwa tugas Dewan harus diutamakan daripada urusan lain, namun pada kenyataannya Dewan selalu mengutamakan urusan politik. Selain itu, masyarakat juga mengkritik bahwa anggota Dewan Perwakilan Rakyat Daerah dinilai tidak profesional, itu dikarenakan Dewan Perwakilan Rakyat Daerah belum mampu mengoptimalkan fungsi pengawasan, dengan indikator penyerapan anggaran oleh eksekutif berjalan nyaris tanpa pengawasan yang berarti.. Bahkan, sangat sering terjadinya gelombang protes dari kalangan aktivis dan mahasiswa yang pro demokrasi terhadap lembaga perwakilan rakyat daerah yang dianggap tidak optimal dalam menjalankan sistem pemerintahan di daerah. (3) Sejatinya dalam mewujudkan pemerintahan yang baik, tiap-tiap masyarakat juga harus berperan serta dalam menyelenggarakan tata kelola pemerintahan yang baik. Jadi, yang dimaksud dengan tata kelola pemerintahan yang baik tersebut merupakan suatu bentuk maupun wujud tanggung jawab yang meliputi wewenang Administrasi, wewenang Ekonomi hingga wewenang Politik demi mengatur segala permasalahan sosial daerah tersebut.
\end{abstract}

Kata kunci: fungsi pengawasan DPRD, tata kelola pemerintahan yang baik.

\section{PENDAHULUAN}

ewan Perwakilan Rakyat Daerah
(DPRD) berdasarkan ketentuan Undang-Undang No. 17 Tahun 2014 tentang MPR, DPR, DPD dan DPRD adalah mitra sejajar dengan pemerintah daerah. DPRD dalam melaksanakan tugasnya, dibekali dengan` tiga fungsi, yaitu fungsi legislasi, anggaran dan pengawasan. DPRD, sebagai lembaga perwakilan rakyat di daerah mempunyai peran yang penting dalam mewujudkan tata kelola pemerintahan yang baik. Peran tersebut, diwujudkan dalam tiga fungsi, yaitu legislasi, anggaran dan pengawasan. Namun, dalam pelaksanaan ketiga fungsi tersebut, DPRD masih mengalami hambatan, sehingga fungsi DPRD perlu dioptimalkan.
Fungsi pengawasan DPRD adalah pengawasan politik dan kebijakan yang bertujuan untuk memelihara akuntabilitas publik, terutama lembaga-lembaga yang berkaitan langsung dengan pelaksanaan kebijakan dan program pemerintahan serta pembangunan di daerah. Dalam tata kelola kepemerintahan yang baik, pengawasan berperan memberikan umpan balik kepada pemerintah daerah serta berfungsi sebagai bagian dari sistem peringatan dini bagi pemerintah daerah. Masalah kualitas anggota DPRD sering kali menjadi fenomena yang dikeluhkan oleh masyarakat. Beragamnya latar belakang anggota DPRD, baik pendidikan maupun pekerjaan berimbas pada kurang efektif dan maksimalnya pengawasan, karena jangkauan ruang lingkup pengawasan yang cukup luas. 
Program kerja yang jelas dan terukur sangat dibutuhkan dalam melaksanakan tugas pengawasan. Pengawasan yang dilaksanakan selama ini terkesan sporadis dan reaktif, tanpa program yang mengacu pada tujuan, sasaran dan ruang lingkup pengawasan DPRD. fungsi pengawasan yang dilaksanakan oleh DPRD masih sebatas jika ada kasus atau temuan, tidak didasarkan pada tugas rutin DPRD. Suatu negara, terlebih dalam negara yang sedang membangun, pengawasan itu sangat penting, baik pengawasan secara vertikal, horizontal, eksternal, preventif maupun represif agar maksud dan tujuan yang telah ditetapkan dapat tercapai. Lemahnya pengawasan berarti mendekatkannya kepada pelaksanaan kerja yang tidak sempurna, sehingga menjauhkannya dari tujuan yang hendak dicapai dan semakin banyak peluang untuk penyalahgunaan kekuasaan.

Sebaliknya, kuatnyakontrolatauketatnya pengawasan maka semakin sempurna pelaksanaannya kerja sehingga tujuan dapat diraih dan penyalahgunaan kekuasaan dapat dihindarkan, yang pada akhirnya hak asasi rakyat dapat terwujud. Dalam negara demokrasi, rakyat lah yang menentukan tujuan dan rakyat pula yang menjadi tujuan, administrasi Negara hanyalah alat untuk mengabdi kepada kepentingan rakyat yang menjadi tujuan. Pengawasan yang dilakukan bukan hanya pada eselon tertinggi, tetapi harus berlangsung terus sampai dengan eselon yang terendah. Jadi pengawasan bersifat menyeluruh dan bukan parsial. Tugas pengawasan sebenarnya merupakan tugas yang terberat karena memerlukan energi dan banyak waktu. Namun perencanaan dan pengorganisasian dapat dibuat satu kali, tetapi pengawasan tidak cukup satu kali melainkan terus menerus sampai perencanaan selesai.

Indonesia telah mengalami sejarah panjang mengenai perjalanan sistem pemerintahan dan tata kelola pemerintahannya. Dinamika tata kelola pemerintahan mewarnai perjalanan republik ini seiring bergantinya rezimrezim yang berkuasa. Dimulai ketika orde lama dengan tata kelola pemerintahan yang terlihat banyak melakukan politisasi terhadap sektor publik dan dilanjutkan dengan orde baru yang mengalami pemusatan kekuasaan pada presiden, baik akibat konstitusi maupun tidak berfungsi dengan baiknya lembaga tertinggi dan tinggi negara yang semakin tidak mengarah kepada tata kelola pemerintahan yang baik. Angin segar berembus sejak meletusnya reformasi tahun 1998 yang menuntut perombakan sistem pemerintahan menuju pemerintahan yang lebih demokratis dan bersih sehingga penerapan Good Governance bisa diterapkan.

Paradigma lama pemerintahan orde baru yang cenderung menggunakan kekuasaan dan pemaksaan kini berubah menjadi kewenangan untuk pelayanan masyarakat dan pemberdayaan masyarakat. Sejalan dengan perubahan era reformasi tersebut, baik secara internal maupun perubahanperubahan lingkungan strategis yang sudah merupakan keharusan setiap aparatur negara memahami dan melaksanakan dengan baik.

UNDP mendefinisikan good governance adalah sebagai "the exercise of political economic, and administrative authority to manage a nations affair at all levels". Dengan demikian governance memiliki tiga pilar yang berkaitan dengan economic, political, dan administration. Sehingga secara umum good governance adalah mengenai tata pemerintahan yang baik sehingga penyelenggara manajemen pembangunan dapat bersatu dan bertanggung jawab sejalan dengan prinsipprinsip demokrasi dan pasar yang efisien. Tata kelola pemerintahan yang baik tersebut meliputi pemerintah dan sektor swasta sehingga dapat menciptakan kredibilitas publik dan melahirkan manajerial yang handal. 
Sejak pascareformasi, Indonesia telah menjalani 19 tahun kehidupan demokrasi yang lebih baik dari sebelumnya. Pemerintahan yang lebih transparan dan demokratis seakan sudah menjadi arah pergerakan pemerintahan sekarang. Namun, apakah saat ini tata kelola pemerintahan kita sudah mencapai good governance sebagaimana cita-cita reformasi? Cita-cita reformasi adalah menginginkan terjadinya perubahan tata kelola pemerintahan yang lebih baik untuk terwujudnya kesejahteraan yang maksimal, membangun pemerintahan yang bersih dan transparan, pemerintahan yang pro rakyat, dan pemerintahan yang pro demokrasi.

Namun, saat ini kita menyaksikan jika pascareformasi berbagai permasalahan bangsa masih saja terus terjadi, mulai dari korupsi, kolusi, nepotisme yang masih bercongkol saja di setiap lini birokrasi di negeri kita. Selain itu, masalah penegakan hukum yang sulit berjalan. Penegakan hukum yang cenderung terkesan tebang pilih dan tidak berkutik apabila sudah berhadapan dengan pemodal, monopoli dalam kegiatan perekonomian, kesejahteraan masyarakat yang masih rendah, disparitas ekonomi masyarakat yang semakin tinggi, pembangunan yang pesat namun kurang memperhatikan kesejahteraan rakyat, pengangguran yang semakin meningkat tiap tahun akibat pertumbuhan penduduk tidak sebanding dengan banyaknya lapangan kerja, hingga munculnya konflik-konflik di berbagai daerah yang dapatmengancam persatuan dan kesatuan negara republik Indonesia.. Bahkan kondisi saat ini pun masih banyak faktorfaktor penghambat majunya pemerintahan yang baik yaitu masih banyaknya perilaku yang bertentangan dengan kaidah good governance sebagaimana cita-cita reformasi. Maka, penulis tertarik untuk mengadakan penelitian tentang "Fungsi Pengawasan DPRD dalam Mewujudkan Tata Kelola Pemerintahan yang Baik di Kota Depok Provinsi Jawa Barat"

\section{Identifikasi Masalah}

Berdasarkan latar belakang penelitian tersebut dapat diidentifikasi masalah yang ditemukan yaitu:

1. Kurang jelasnya mekanisme pengawasan DPRD dalam Mewujudkan Tata Kelola Pemerintahan yang baik;

2. Kurangnya pemahaman anggota PDRD dalam melaksanakan pengawasan DPRD dalam Mewujudkan Tata Kelola Pemerintahan yang baik;

3. Adanya kendala yang terjadi dalam sistem pengawasan yang dilakukan oleh DPRD dalam pengawasan;

4. Kurang optimalnya fungsi pengawasan yang dilakukan oleh DPRD dalam pengawasan DPRD untuk Mewujudkan Tata Kelola Pemerintahan yang baik.

5. Anggota DPRD yang terpilih, pada kenyataannya belum optimal melakukan fungsi pengawasan. Karena sistem partai yang terpusat membuat anggota DPRD menjadi lebih berpihak kepada partai sebagai sumber legitimasi daripada berpihak pada pemilih dan masyarakat.

6. Masalah kualitas anggota DPRD sering kali menjadi fenomena yang dikeluhkan oleh masyarakat. Beragamnya latar belakang anggota DPRD, baik pendidikan maupun pekerjaan berimbas pada kurang efektif dan maksimalnya fungsi pengawasan, karena jangkauan ruang lingkup pengawasan yang cukup luas.

\section{Pembatasan dan Rumusan Masalah}

Mengingat permasalahan yang akan dibahas dalam penelitian ini sangat luas, maka perlu pembatasan masalah. Adapun yang akan dikaji dalam penelitian ini adalah: "Fungsi Pengawasan DPRD dalam Mewujudkan Tata Kelola Pemerintahan yang Baik di Kota Depok Provinsi Jawa Barat".

Berdasarkan latar belakang penelitian maka rumusan masalah dalam penelitian Fungsi Pengawasan DPRD dalam 
Mewujudkan Tata Kelola Pemerintahan yang Baik sebagai berikut.

1. Bagaimana fungsi pengawasan DPRD dalam mewujudkan tata kelola pemerintahan yang baik di Kota Depok Provinsi Jawa Barat?

2. Faktor-faktor apa saja yang penghambat PDRD dalam pengawasan untuk mewujudkan tata kelola pemerintahan yang baik di Kota Depok Provinsi Jawa Barat.

3. Bagaimana upaya revitalisasi fungsi pengawasan DPRD dalam mewujudkan tata kelola pemerintahan yang baik di Kota Depok Provinsi Jawa Barat?

\section{Maksud dan Tujuan Penelitian}

Maksud dari pada penelitian ini adalah untuk mengetahui tentang fungsi pengawasan DPRD dalam mewujudkan tata kelola pemerintahan yang baik di Kota Depok Provinsi Jawa Barat.

Adapun tujuan yang ingin dicapai melalui penelitian ini dapat dibagi dalam tiga hal, yaitu:

Mengidentifikasi dan menganalisis fungsipengawasan DPRD dalam Mewujudkan Tata Kelola Pemerintahan yang Baik di Kota Depok Provinsi Jawa Barat.

1. Mendeskripsikan dan menganalisis upaya-upaya revitalisasi yang di lakukan oleh DPRD untuk mewujudkan tata kelola pemerintahan yang baik di Kota Depok Provinsi Jawa Barat.

2. Untuk mengetahui Faktor-faktor apa saja yang penghambat PDRD dalam pengawasan untuk mewujudkan tata kelola pemerintahan yang baik di Kota Depok Provinsi Jawa Barat.

\section{Kegunaan Penelitian}

Bahwa hasil penelitian ini diharapkan dapat memberikan nilai dan hasil bagi semua pihak, baik secara teoretis maupun praktis.
Secara teoretis penelitian ini diharapkan dapat memberikan kontribusi pemikiran dalam Ilmu Pemerintahan, khususnya Ilmu pemerintahan terapan (bestuurskunde) yang berkaitan dengan fungsi pengawasan DPRD dalam mewujudkan tata kelola pemerintahan yang baik di Kota Depok Provinsi Jawa Barat serta hambatan dan solusi untuk mengatasinya.

Adapun kegunaan praktis dari penelitian ini, yaitu :

a. Bagi penulis hasil penelitian ini diharapkan dapat memberikan kontribusi dalam pengembangan ilmu pengetahuan tentang fungsi pengawasan DPRD dalam Mewujudkan Tata Kelola Pemerintahan yang Baik di Kota Depok Provinsi Jawa Barat.

b. Bagi akademisi hasil penelitian ini diharapkan dapat memberikan kontribusi dalam pengembangan ilmu pengetahuan tentang fungsi pengawasan DPRD dalam Mewujudkan Tata Kelola Pemerintahan yang Baik di Kota Depok Provinsi Jawa Barat.

c. Bagi masyarakat hasil penelitian ini diharapkan dapat memberikan informasi kepada masyarakat tentang fungsi pengawasan DPRD dalam Mewujudkan Tata Kelola Pemerintahan yang Baik di Kota Depok Provinsi Jawa Barat.

d. Bagi Pemerintah Kota Depok dan DPRD Kota Depok hasil penelitian ini diharapkan dapat memberikan referensi data bagi pemerintah Kota Depok dan DPRD Kota Depok serta saran untuk membenahi system dan controlling di Kota Depok Provinsi Jawa Barat khususnya tentang pelaksanaan fungsi pengawasan DPRD dalam Mewujudkan Tata Kelola Pemerintahan yang Baik di Kota Depok Provinsi Jawa Barat agar tidak ada penyelewengan sehingga akan memberikan kemudahan dalam mencapai tujuan Negara yang telah diamanatkan oleh UUD 1945. 


\section{METODE PENELITIAN}

\section{Desain Penelitian}

Penelitian ini menerapkan desain kualitatif yaitu penelitian yang pusat perhatiannya bergantung pada prinsip umum yang menjadi dasar wujud suatu gejala kehidupan manusia, atau juga pola yang dianalisis dari indikasi sosial budaya melalui budaya masyarakat tersebut guna mendapat representasi. Pendekatan Penilaian ada dua, yaitu:

\section{Pendekatan Penilaian Deskriptif}

Metode yang digunakan penulis guna menyelesaikan tesis adalah metode deksriptif. Metode ini bertujuan untuk memaparkan situasi atau peristiwa melalui teks dengan cara mendeskripsikan sebuah variabel yang berkaitan dengan masalah dan unit yang diamati.

2. Paradigma Penelitian Konstruktivisme

Paradigma ialah kerangka atau pola pikir tentang cara pandang peneliti terhadap fakta yang ada. Dalam penelitian ini, paradigma yang digunakan adalah paradigma konstruktivisme. Konstruktivisme bertolak belakang dengan positivisme yang memisahkan objek dan subjek dalam komunikasi. Dalam pandangan konstruktivisme, bahasa bukan hanya dilihat sebagai alat untuk memahami realita objektif belaka dan dipisahkan dari subjek sebagai penyampaian pesan. Subjek di dalam konstruktivisme dianggap sebagai faktor utama dalam kegiatan komunikasi serta hubungan-hubungan sosialnya.

\section{Sumber dan Teknik Pengumpulan Data}

Sumber data merupakan asal peneliti mendapatkan informasi guna kepentingan penelitian. Sumber data diklasifikasikan menjadi dua kategori data, yaitu: data primer dan sekunder. Data primer merupakan data yang diperoleh secara langsung melalui informan, sedangkan data sekunder adalah data yang didapatkan melalui penelitian yang sudah ada sebelumnya.

"Strategi purposive dilakukan guna pemilihan informan. Informan dipilih berdasarkan tujuan dan pertimbangan peneliti. Hal ini didasari karena adanya asumsi bahwa subjek merupakan yang paling tahu mengenai tema yang sedang diteliti." (Idrus, 2009: 25) .

Informan anggota DPRD Kota Depok dalam penelitian ini adalah:

1. Ketua Komisi A Bidang Pemerintahan dan Hukum;

2. Ketua DPRD Kota Depok Badan Anggaran

3. Ketua Komisi B Bidang Perekonomian dan Keuangan;

4. Wakil Ketua Komisi A Bidang Pemerintahan dan Hukum;

5. Wakil Ketua Komisi B Bidang Perekonomian dan Keuangan; dan

6. Fraksi-Fraksi DPRD Kota Depok.

Proses pendekatan terhadap informan dalam penelitian ini dilakukan melalui pendekatan struktural, di mana dalam hal ini peneliti menghubungi informan untuk meminta izin dan kesediaannya untuk diteliti. Selain itu juga peneliti menggunakan pendekatan personel (rapport), di mana peneliti berkenalan dengan informan penelitian agar terjalin secara akrab sehingga dapat memperoleh informasi yang lebih banyak lagi.

\section{- Akses Informan}

Informan merupakan sumber atau kunci utama dalam memperoleh informasi terkait kegiatan observasi, oleh karena itu akses merupakan hal yang penting guna mendapatkan informasi dari informan. "Akses informan merupakan gerbang peneliti untuk masuk ke dalam dunia yang dialami oleh informan. Cara peneliti mendapatkan 
akses informan penting untuk diperhatikan. Akses dapat diperoleh melalui 3 cara meliputi perkenalan secara langsung, diperkenalkan, atau pertemuan tidak sengaja di tempat penelitian". (Kuswarno 2009: 61).

\section{- Rapport Informan}

Menjagahubungan baikdengan informan (rapport) merupakan hal terpenting dalam penelitian studi deskriptif kualitatif, mengingat penelitian tidak bisa ditentukan berlangsung dalam waktu yang cepat atau dalam hitungan jam. Dalam menjalin hubungan baik dengan (rapport) dengan informan, hal yang pertama peneliti lakukan yaitu berkomunikasi dengan informan dengan cara memperkenalkan diri sebelum melakukan wawancara, kemudian bertanya untuk meminta kesediaan informan dalam memberikan informasi terkait penelitian. Setelah itu, peneliti menyampaikan kertas untuk kemudian diisi oleh informan serta selanjutnya menanyakan jadwal yang disediakan informan untuk melangsungkan kegiatan wawancara.

\section{- Profil Informan}

Informan dalam penelitian ini merupakan bagian dari penelitian guna memperoleh data informasi. Informan dalam penelitian ini berjumlah enam orang informan yang terdiri dari:

1. Ketua Komisi A Bidang Pemerintahan dan Hukum DPRD Kota Depok

2. Ketua DPRD Kota Depok Badan Anggaran

3. Ketua Komisi B Bidang Perekonomian dan Keuangan DPRD Kota Depok

4. Wakil Ketua Komisi A Bidang Pemerintahan dan Hukum

5. Wakil Ketua Komisi B Bidang Perekonomian dan Keuangan

6. Fraksi-Fraksi DPRD Kota Depok

\section{Teknik Pengumpulan Data}

Creswell dalam Kuswarno (2013: 47), menjabarkan teknik utama pengumpulan data yang bisa dilakukan dalam studi deskriptif kualitatif, yaitu partisipasi (participation), observasi (observation), dokumentasi (documentation), wawancara (interview), dan studi pustaka (literature review)

\section{Metode Analisis Data}

Miles \& Huberman (1992) mengemukakan tiga tahapan yang harus dikerjakan dalam menganalisis data penelitian kualitatif, yaitu: reduksi data (data reduction), paparan data (data display), dan penarikan kesimpuan dan verifikasi (conclusion drawing /verifiying).

Analisis data kualitatif dilakukan secara bersamaan dengan proses pengumpulan data berlangsung, artinya kegiatan-kegiatan tersebut dilakukan juga selama dan sesudah pengumpulan data (Gunawan, 2013; 211).

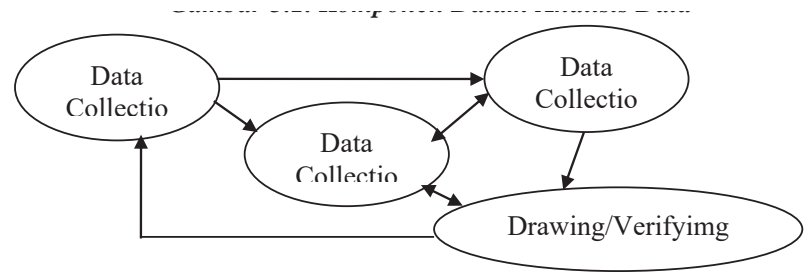

Gambar 1.

Komponen dalam analisis data (Interactivemodel)

Sumber: (Gunawan, 2013: 211)

\section{Unit dan Teknis Analisis Data}

Proses analisis data jika ditinjau secara menyeluruh melibatkan usaha memaknai data yang berupa gambar atau teks. Sebelum melakukan analisis, ada beberapa langkah yang harus dipersiapkan, yaitu Menyiapkan data, Menyajikan data, dan Menginterpretasi makna secara luas dari data tersebut.

Data yang sudah terkumpul kemudian dianalisis melalui empat tahap berikut. mentranskripsikan data, kategorisasi data, verifikasi data, interpretasi data, dan deskripsi data. 
Mentranskripsikan data yaitu peneliti melakukan pengalihan data rekaman ke dalam bentuk tesis. Kategorisasi yaitu peneliti melakukan klasifikasi data terkait dengan hal-hal yang diamati kemudian mengategorikannya menjadi data sekunder \& lapangan lalu menghubungkan sekumpulan data yang telah terkumpul guna mendapatkan makna yang sesuai. Verifikasi yaitu pengecekan ulang data untuk mendapatkan akurasi dan validitas data. Interpretasi dan deskripsi yaitu di mana peneliti berusaha menghubungkan sejumlah data yang ada guna memperoleh makna dari keterkaitan data tersebut.

\section{Teknik Pemeriksaan Keabsahan Data}

Dalam teknik pemeriksaan keabsahan data dilakukan uji ada dua, yaitu:

a. Validitas data yaitu membuktikan bahwa apa yang diamati oleh peneliti sesuai dengan realita yang ada, dan penjelasan yang diberikan sesuai dengan yang terjadi atau keadaan sebenarnya.

b. Realibilitas data yaitu Realibilitas berkenaan dengan metode yang serupa apakah akan menunjukkan hasil yang sama. Jadi realibilitas menunjukkan adanya konsistensi, yakni memberikan hasil yang konsisten sehingga dapat dipercaya.

Triangulasi secara sederhana dapat diartikan sebagai teknik guna memeriksa keabsahan data menggunakan perbandingan antara teori, sumber maupun metode penelitian. Karena itu, Moelong membagi teknik pemeriksaan keabsahan data menjadi tiga cara, yaitu: triangulasi sumber, triangulasi teknik/metode, dan triangulasi teori.

\section{Kategorisasi}

Dalam tahapan penelitian, pengolahan data bersifat dinamis yang dilakukan pada saat pengumpulan data. Data yang diperoleh dari sumber data dianalisis demi konsistensi dan keteraturan yang disusun berdasarkan kategori informan, yaitu Profil informan, Usia, Jenis kelamin, pendidikan, dan lain-lain.

\section{HASIL PENELITIAN DAN PEMBAHASAN}

\section{Fungsi Pengawasan DPRD dalam Mewujudkan Tata Kelola Pemerintahan yang Baik}

Hasil wawancara dengan salah satu anggota DPRD Kota Depok, Ahmad Sofian, berpendapat bahwa pengawasan DPRD dalam mewujudkan tata kelola pemerintahan yang baik:

\begin{abstract}
"Pengawasan yang dilakukan DPRD adalah pengawasan politik bukan pengawasan teknis. Untuk itu, DPRD dilengkapi dengan beberapa hak, antara lain Hak Interpelasi, Hak Angket, dan Hak Menyatakan Pendapat, karena dengan adanya hak-hak ini dapat memberikan kredibilitas DPRD untuk menjalankan fungsinya."
\end{abstract}

Sementara itu, menurut Andi Amiruddin dari Fraksi Partai Golkar memberikan pendapat yang sama dengan rekannya Ahmad Sofian menjabarkan hak-hak DPRD sebagai berikut.

"Hak interpelasi dengan maksud para anggota Dewa Perwakilan rakyat Daerah dapat meminta keterangan dari kepala daerah tentang kebijakan yang meresahkan dan nantinya berdampak luas pada masyarakat. Dan hak angket dilakukan untuk menyelidiki kebijakan tertentu dari kepala daerah yang mana nantinya akan berdampak luas pada kehidupan masyarakat dan diduga bertentangan dengan peraturan perundang-undangan. Sedangkan hak menyatakan pendapat fungsinya berbeda dengan mosi tidak percaya, karena tidak dapat menjatuhkan kepala daerah, tetapi hanya berupa pengusulan pemberhentian kepala daerah kepada presiden". 
Lanjut Andi Amiruddin mengemukakan bahwa:

"Dewan Perwakilan Rakyat Daerah (DPRD) merupakan salah satu unsur penentu atas keberhasilan pelaksanaan pemerintahan di daerah, karena DPRD merupakan bagian dari pemerintah daerah dan mitra dari Eksekutif dalam menjalankan fungsi pemerintahan. Dalam posisinya sebagai mitra pemerintah daerah telah diatur di dalam undang-undang tentang fungsi dan peran yang harus diemban dalam menjalankan tugasnya sebagai Representasi dari Masyarakat yang Diwakilinya. Ada tiga fungsi yang menjadi kewenangan DPRD untuk membantu pemerintah dalam menjalankan roda pemerintahan, yakni Fungsi Legislasi, Fungsi Anggaran dan Fungsi Pengawasan. Dalam sejarah perkembangan fungsi dan peran DPRD sebagai mitra pemerintah, mulai sejak pemerintahan orde baru hingga orde reformasi seperti sekarang ini, ada kecenderungan sebagian masyarakat menilai bahwa ketiga fungsi tersebut di atas, satu di antaranya dianggap kurang berjalan secara maksimal, yakni Fungsi Pengawasan (Controlling), fungsi tersebut bagi sebagian orang dianggap tidak maksimal, karena secara faktual DPRD dianggap sangat lemah dan kurang mampu untuk melakukan penekanan atau dianggap kurang mampu untuk mengurangi tingkat penyelewengan yang dilakukan pihak Eksekutif dalam menjalankan tugasnya selaku Eksekutor, hal ini ditandai dengan masih dijumpainya berbagai Kecurangan, Ketidakadilan, Nepotisme Dan Korupsi yang cukup signifikan, yang kemudian pada akhirnya akan menggerogoti kehidupan masyarakat secara umum, padahal sangat jelas telah diatur di dalam Undang-Undang No. 32 Tahun 2004 tentang pemerintahan kemudian diubah UU No. 23 Thn 2014 tentang Pemerintahan. Daerah dan Undang-Undang No. 27 tahun 1999 tentang MPR, DPR, DPD dan DPRD Provinsi/Kabupaten Kota, menerangkan bahwa anggota Legislatif memiliki tiga fungsi, khususnya fungsi pengawasan, yang dalam menjalankan fungsi ini, DPRD memiliki kewenangan secara politis untuk melakukan kontrol terhadap pemerintah dalam bentuk memberikan teguran atau arahan atas kebijakan yang akan dijalankan oleh pemerintah.

Jika penguatan fungsi legislatif tersebut dapat dilaksanakan dengan konsisten dan terprogram, dapat diharapkan adanya peningkatan performance DPRD. Ke depan hal ini merupakan tuntutan mengingat UndangUndang No. 23 Tahun 2014 menempatkan DPRD dan kepala daerah sebagai dua unsur pemerintahan daerah yang memiliki hubungan kemitraan yang menuntut adanya kesejajaran dalam kualitas kerja. Salah satu aspek penting dalam pelaksanaan rencana sebagai bagian dari proses perencanaan yang menyeluruh adalah pengawasan. Pengawasan adalah salah satu unsur dalam rangka meningkatkan pelaksanaan tugas-tugas umum pemerintahan dan pembangunan.

Berdasarkan hasil wawancara yang dilakukan peneliti dengan Suhirman (Ketua Komisi B Bidang Perekonomian dan Keuangan):

"Secara umum fungsi pengawasan bertujuan untuk mengarahkan agar yang telah direncanakan sebelumnya dapat berjalan secara maksimal sesuai harapan bersama. Demikian pula halnya dengan fungsi pengawasan DPRD, meskipun hanya pengawasan yang bersifat politis, akan tetapi pada pengawasan ini juga diharapkan akan dapat menjadi kendali bagi pemerintah dalam menjalankan sistem dan mekanisme pemerintahan. Secara khusus Pengawasan Legislatif 
(DPRD) pada hakikatnya adalah lembaga pengawas yang bertugas mengawasi tindakan pemerintah daerah provinsi dan kabupaten/kota. Pengawasan legislatif ini tidak terbatas pada tata cara pemerintahan saja, tetapi juga terhadap tata cara penyelenggaraan keuangan daerah. Pengawasan legislatif merupakan pengawasan politik terhadap penyelenggaraan pemerintahan daerah. Sebagai mitra kerja eksekutif, DPRD perlu memberikan bantuan agar pelaksanaan amanat Rencana Pembangunan Jangka Menengah Daerah (RPJMD) oleh pemerintah daerah dapat tercapai secara efisien dan efektif dari berbagai sudut pandang termasuk politik. Karena pengawasan legislatif telah diupayakan secara maksimal, akan tetapi hasil yang dicapai dianggap belum maksimal oleh berbagai pihak yang ditandai dengan masih ditemukannya berbagai kelemahan dan kekurangan pada tahap implementasi kebijakan pemerintah, khususnya mengenai kelemahan pihak DPRD dalam mengawasi jalannya perjanjian antara pemerintah dengan pihak ketiga di Kota Depok, dan masih dijumpainya pula kelemahan-kelemahan pada tubuh DPRD itu sendiri."

Untuk mewujudkan tata kelola pemerintahan yang baik, perlu adanya kemitraan kerja sama antara pemerintah dengan DPRD. Oleh karena itu setiap kegiatan bagaimana pun bentuk dan sifatnya tentunya memerlukan pengawasan demi lancarnya proses pembangunan yang terarah sesuai dengan program untuk terciptanya hasil yang kita harapkan. Untuk mencapai tujuan pembangunan nasional, maka diharapkan adanya pengawasan yang baik, karena pelaksanaan pembangunan yang meliputi seluruh aspek kehidupan yang kompleks ini, tentunya sangat dirasakan pentingnya pengawasan yang dilaksanakan secara efisien dan efektif sehingga apa yang diharapkan dapat tercapai dan tidak terjadi penyimpangan-penyimpangan yang tidak diinginkan.

Berdasarkan hasil wawancara dengan Ketua Komisi A Bidang Pemerintahan dan Hukum, Maryadi, mekanisme pengawasan yang dilakukan DPRD di Kota Depok adalah sebagai berikut.

\section{Tahap Musrenbang}

Pada tahap ini merupakan tahapan perencanaan pembangunan yang secara hierarki terbagi atas tiga tingkatan untuk kategori perencanaan pembangunan di tingkat kabupaten/kota, yakni MusrenbangtingkatDesa atau kelurahan, Musrenbang tingkat Kecamatan dan Musrenbang tingkat kabupaten/kota yang dalam pelaksanaannya tentunya dihadiri oleh pihak-pihak terkait berdasarkan tingkatan pemerintahan.

\section{Tahap Pembahasan RAPBD}

Kegiatan ini dilakukan oleh pemerintah atau (SKPD) terkait bersama DPRD, fungsi DPRD adalah sebagai mitra dari pemerintah daerah sekaligus sebagai representasi dari masyarakat untuk memperjuangkan apa yang menjadi kebutuhan dan aspirasi dari masyarakat yang diwakilinya.

3. Tahap Perjanjian dengan Pihak ketiga (Tender)

Setelah selesai pembahasan RAPBD yang ditandai dengan ditetapkannya APBD tahun berjalan, kegiatan selanjutnya adalah proses pelelangan proyek (Tender) yang dilakukan oleh pemerintah atau SKPD terkait yang dihadiri oleh peserta tender atau pihak ketiga dan anggota DPRD

\section{Penentuan Agenda Pengawasan} Kegiatan yang dilakukan oleh DPRD untuk menentukan agenda dan jadwal pengawasan, yang menetapkan kapan pengawasan itu dimulai, siapa yang berkompeten dan komisi apa yang berhak untuk melakukan pengawasan, 
tentu penetapan agenda pengawasan ini dilakukan untuk menghindari terjadinya kesimpangsiuran dalam menjalankan fungsi pengawasan, sebab selama ini sering terjadi kesalahanpahaman dalam melakukan pengawasan karena tidak adanya penentuan dan penetapan agenda sebelum melakukan pengawasan.

\section{Penentuan Metode Pengawasan}

Merupakan hal yang sangat penting dan menentukan tingkat keberhasilan dan efektivitas fungsi pengawasan, sebab perlu diketahui bahwa metode pengawasan politik dengan metode pengawasan fungsional sangat berbeda, hal inilah yang sering menjadi pemicu munculnya kesalahan dan kesimpangsiuran pengawasan yang dijalankan oleh DPRD sebab sering kali teknik pengawasan fungsional ingin diterapkan dalam pengawasan politik, padahal substansinya sangat berbeda, DPRD sebagai lembaga pengawasan politik memiliki beberapa metode pengawasan, antara lain; 1) Pengaduan; 2) Rapat dengar pendapat umum (Public Hearing); 3). Kegiatan kunjungan kerja dan 4) Rapat kerja Komisi dengan Pemerintah, tentunya keempat metode pengawasan ini harus dipahami benar oleh anggota DPRD, agar tidak salah kapra dalam menjalankan fungsi pengawasan.

\section{Membangun Jaringan}

Membangun jaringan dalam menjalankan fungsi pengawasan bagi DPRD juga merupakan hal yang sangat penting, sebab DPRD memiliki keterbatasan untuk melakukan pengawasan, baik itu keterbatasan dari segi kuantitas, keterbatasan kualitas maupun keterbatasan dari segi waktu;

\section{Melaksanakan Pengawasan}

Pelaksanaan pengawasan terhadap perjanjian antara pemerintah dengan pihak ketiga secara praktis berlangsung pada saat kegiatan tender berlangsung dan berakhir pada setiap tahun anggaran atau sampai pada saat proyek tersebut telah diterima oleh pemerintah selaku pemilik atau pengguna proyek.

\section{Membuat Laporan}

Agar pelaksanaan pengawasan DPRD terhadap perjanjian antara pemerintah dengan pihak ketiga dapat berjalan secara efektif dan dapat dipertanggungjawabkan secara administratif, maka kegiatan pengawasan yang telah dilaksanakan harus dibuatkan laporan sebagai pertanggungjawaban kepada pimpinan komisi atau pimpinan DPRD ataupun kepada pihak-pihak yang terkait dengan pelaksanaan pengawasan.

\section{Tindak Lanjut Hasil Pengawasan}

Setiap pengawasan yang telah dilakukan oleh DPRD tentunya tidak hanya berakhir pada pembuatan atau penyampaian dalam bentuk laporan, akan tetapi jika terbukti ada temuan pelanggaran yang dilakukan oleh pihak yang diawasi, maka selanjutnya harus ditindaklanjuti dengan melakukan monitoring dengan tujuan agar apa yang menjadi temuan di lapangan dapat dihentikan atau dapat dicegah melalui pengawasan secara berkala. Selain itu, memonitoring juga dilakukan untuk mengetahui apakah kasus yang telah menjadi temuan mendapatkan tindak lanjut dari pimpinan atau pihak-pihak yang berkompeten untuk memberi justifikasi terhadap permasalahan yang terjadi.

\section{Menilai Laporan Keterangan Pertanggungjawaban (LKPJ)}

Tahapan terakhir dari mekanisme pengawasan terhadap perjanjian antara pemerintah dengan pihak ketiga adalah menilai laporan keterangan 
pertanggungjawaban (LKPJ) bupati/ wali kota pada setiap akhir tahun anggaran atau akhir masa jabatan, dalam kegiatan ini DPRD melakukan penilaian terhadap LKPJ bupati/wali kota, apakah pelaksanaan kegiatan yang telah dilakukan selama satu tahun sesuai dengan rencana sebelumnya atau tidak, jika ternyata apa yang telah dilakukan selama satu tahun anggaran ada ketidaksesuaian dengan rencana yang telah ditetapkan sebelumnya, maka pihak DPRD dapat memberikan rekomendasi untuk dilakukan perbaikan. Karena berdasarkan aturan perundangundangan apabila dalam LKPJ bupati/ wali kota ternyata terdapat kekurangan atau ketidaksesuaian dengan rencana sebelumnya, maka DPRD tidak lagi memiliki kewenangan untuk menerima atau menolak LKPJ, tetapi hanya sebatas mendengarkan.

\section{Faktor yang Penghambat dalam Pengawasan DPRD}

Berdasarkan hasil wawancara dengan Andi Amiruddin, Anggota DPRD Fraksi Partai Golkar mengungkapkan sebagai berikut.

"Ada beberapa faktor dan hambatan yang dialami DPRD Kota Depok, yaitu kelemahan internal di DPRD termasuk kurangnya Sumber Daya Manusia, mengingat Kota Depok yang sangat luas daerahnya dengan penduduk yang sangat padat, juga keterbatasan kualitas sumber daya manusia, permasalahan yang berhubungan dengan anggaran juga masalah-masalah teknis yang datang baik dari internal maupun eksternal. Keterbatasan sumber daya manusia yang ahli dalam hal pengawasan terhadap APBD, kondisi itu menjadi hal yang sangat memprihatinkan apabila dewan keliru dalam memberikan penilaian terhadap kinerja eksekutif apalagi menyangkut pengelolaan keuangan daerah yang sangat rentan terhadap penyelewengan. Meskipun begitu, DPRD Kota Depok tetap berusaha untuk terus meningkatkan kinerjanya dalam menjalankan tugas dan fungsinya sebagai wakil rakyat dengan baik. Perlu menanamkan kesadaran dan pengetahuan tentang pentingnya kedisiplinan di dalam menjalankan tugas dan kedudukan dan posisinya di DPRD dapat untuk mewakili suara rakyat dan membantu menyejahterakan rakyat sehingga apa yang akan dilakukan oleh DPRD berorientasi untuk kepentingan rakyat. Faktor lain yang menjadi penghambat adalah kurangnya melibatkan partisipasi aktif dari masyarakat dalam penyusunan dan pengawasan APBD, sehingga kebutuhan masyarakat sering terabaikan.

Hasil wawancara dengan Indra Gunawan, anggota DPRD dari Fraksi PPP mengungkapkan bahwa:

“DPRD Kota Depok juga mengalami beberapa kendala dalam pengawasan seperti halnya faktor yang terjadi di dalam lembaga dan di luar lembaga DPRD sendiri, keterbatasan kualitas Sumber daya manusia, terbatasnya fasilitas dan sarana. Tetapi untuk meminimalisasikan suatu penghambat DPRD Kota Depok memiliki suatu perangkat komisi sesuai bidangnya yang dioptimalkan untuk melakukan pengawasan, Selain itu juga adanya pengawasan lembaga intern dari pemerintah pusat seperti Badan pengawas keuangan dan pembangunan (BPKP) dan Badan Pengawas Daerah (Bawasda) yang merupakan lembaga intern yang membantu DPRD dalam Pemeriksaan keuangan daerah.

\section{Upaya Revitalisasi Fungsi Pengawasan DPRD}

Dewan Perwakilan Rakyat Daerah (DPRD) Kota Depok hingga saat ini terus berbenah. Berbagai upaya terus dilakukan guna meningkatkan pelayanan dan kinerja 
para wakil rakyat yang duduk di Kota Depok. Bahwa di DPRD Kota Depok punya program revitalisasi. Program ini pertama kali diperkenalkan oleh Ketua DPRD Kota Depok. Program revitalisasi ini dikenal dengan program 3R berikut ini.

\section{Revitalisasi Insfrastruktur}

$\mathrm{R}$ yang pertama dalam program $3 \mathrm{R}$ adalah revitalisasi Infrastruktur. Revitalisasi yang dimaksud adalah peningkatan sarana dan prasarana yang ada di DPRD Kota Depok. Pada akhir tahun 2016, DPRD Kota Depok melakukan renovasi terhadap gedung utama sekretariat yang biasa dipakai sebagai ruang paripurna. Gedung yang belakangan diberi nama gedung $\mathrm{H}$. Abdul Samad ini kemudian resmikan pada 9 Januari 2017. Peresmian kala itu dihadiri langsung oleh Gubernur Jawa Barat, dan Wali Kota Depok, serta Ketua DPRD Kota Depok, selaku tuan rumah. Hadir pula unsur Muspida dari sejumlah instansi. Selanjutnya, pada 2017, DPRD Kota Depok kembali melakukan pembenahan infrastruktur besarbesaran. Dua bangunan dirobohkan dan kemudian dibangunlah gedunggedung baru. Bangunan-bangunan baru yang kini telah berdiri antara lain, gedung staf sekretariat, gedung komisi, gedung pertemuan/musala, panggung aspirasi dan gedung fraksi (direnovasi). Bangunan-bangunan ini kemudian diresmikan oleh Wali Kota Depok, pada Januari 2018. Lalu, apa tujuan dari pembangunan tersebut? Menurut Gusli, kantor dewan adalah rumah rakyat. Rakyat adalah pemilik sesungguhnya dari gedung-gedung tersebut. "Kita persembahkan ini untuk rakyat. Ketika mereka ke sini, mereka bisa merasakan kenyamanan yang lebih baik, dari fasilitas-fasilitas gedung ini, "

Hasul wawancara dengan Sekretariat DPRD Kota Depok, Kania Parwanti, warga Kota Depok bisa memakai panggung aspirasi yang teduh ketika hendak menyuarakan aspirasinya, sehingga tak perlu lagi berada di bawah terik matahari. Kemudian, warga juga dapat menikmati fasilitas ruang hearing yang luas dan memadai, sehingga tidak perlu berdesak-desakan dalam ruangan seperti dulu.

"Dan di sini masyarakat bisa beribadah di musala yang cukup sejuk. Semuanya kami bangun untuk kebutuhan dan kenyamanan warga Kota Depok yang bertamu ke sini," Selain fasilitas tersebut, DPRD Kota Depok kini telah memiliki taman. Taman tersebut kini berada tepat di samping agak ke belakang gedung paripurna. Taman ini dihiasi tanaman bunga, air mancur dan gazebo untuk tempat bersantai. Nantinya taman ini akan dilengkapi dengan hot spot yang bisa diakses warga.

\section{Revitalisasi Produk Hukum}

R selanjutnya adalah revitalisasi produk hukum. Produk hukum yang dimaksud adalah Produk Legislasi daerah (Prolegda). Atau biasa disebut Peraturan Daerah (Perda). Perda ini terbagi atas dua, yakni Perda usulan dari Pemda Wali Kota Depok dan Perda hasil inisiatif DPRD Kota Depok. DPRD Kota Depok sendiri menargetkan periode 20142019 bisa menghasilkan seratus Perda inisiatif. Lalu, bagaimana hasilnya? Ternyata produktivitas DPRD Kota Depok dalam merancang Perda tak perlu diragukan lagi. Hingga saat ini target tersebut hampir tercapai. Persentasenya sudah di atas 80 persen. Itu baru Perda inisiatif saja. Jika digabungkan dengan Perda usulan Pemda Wali Kota Depok, totalnya sudah lebih dari seratus. Uniknya, dari seratus Perda inisiatif yang ditarget, delapan puluh persen di antaranya adalah Perda menyangkut budaya. Hal ini dilakukan DPRD agar 
ke depannya, segala kebijakan tentang pembangunan Kota Depok tidak melupakan sisi budayanya.

"Contoh Perda tentang budaya ini, misalnya penamaan jalan di Kota Depok dengan nama-nama pahlawan atau tokoh penting di Kota Depok. Ini penting bagi generasi agar mengetahui sosoksosok yang telah berjasa untuk daerah."

\section{Revitalisasi Birokrasi}

$\mathrm{R}$ yang terakhir adalah revitalisasi birokrasi. Revitalisasi ini lebih ditujukan kepada internal DPRD sendiri, baik staf sekretariatnya maupun anggota legislatifnya. Kedisiplinan adalah kunci utama dalam program ini. Kehadiran staf sekretariatakan diperketat lewat kontrol dari Sekretaris Dewan. Sementara kehadiran dan kode etik dewan lainnya sepenuhnya akan dikontrol oleh Badan Kehormatan. Diharapkan, dengan kedisiplinan ini suasana kerja di DPRD Kota Depok bisa lebih baik. Para staf bisa mengerjakan tugas-tugasnya dengan baik. Para anggota dewan pun bisa melayani masyarakat dengan baik pula. Masalah kedisiplinan ini tak hanya ditekankan ketika oleh ketua Dewan sekarang ini tapi ketua Dewan siapa saja di DPRD kota depok bisa menerapkan kedisiplinan. Bahkan juga punya penekanan tersendiri terkait masalah kedisiplinan. Sama seperti Ketua Dewan, pendahulunya, selama menjabat dikenal sebagai sosok yang rajin berkantor. Pagi-pagi mobilnya tampak sudah terparkir di lobi gedung utama. Hal itu ia lakukan untuk memberi keteladanan terhadap staf dan anggota DPRD lainnya. "Kedisiplinan kita kembali galakan, Khususnya masalah kehadiran. Tiap pagi anggota dewan sudah harus masuk berkantor jika tak ada agenda dinas di luar. Ini penting, jika ada masyarakat yang sewaktu-waktu datang kepada mereka meminta penyelesaian masalah."
Berdasarkan wawancara, 3R di atas prinsip berikutnya yang harus diterapkan oleh suatu negara demi mewujudkan pemerintahan yang baik ialah adanya visi pembangunan yang luas. Visi pembangunan yang luas tersebut maksudnya ialah sebuah visi yang sudah dipertimbangkan masakmasak dan mendalam demi mewujudkan tata kelola pemerintahan yang baik.

Prinsip berikutnya yang perlu
kita ketahui sebagai prinsip tata
kelola pemerintahan yang baik demi menyelenggarakan pemerintahan yang baik ialah ditegakkannya supremasi hukum oleh negara. Supremasi yang dimaksud ialah kekuasaan hukum berikut dengan normanorma hukum yang menjadikan dasar dari keseluruhan hal serta tetap mempunyai prinsip keadilan. Suatu negara yang memiliki orientasi untuk mewujudkan pemerintahan yang baik tentu harus mampu menegakkan supremasi hukum. Hukum tidak boleh pandang bulu. Hukum tidak boleh pandang kasta. Sila kelima Pancasila harus ditegakkan demi mewujudkan prinsip supremasi hukum tersebut. Jika supremasi hukum dapat ditegakkan dengan baik oleh negara, maka hal tersebut akan membawa pengaruh dan efek yang baik khususnya pada tingkat keamanan maupun ketertiban di tengah masyarakat luas.

Prinsip selanjutnya yang patut kita ketahui dalam upaya mewujudkan pemerintahan yang baik ialah adanya tanggapan yang baik dari aparatur negara. Seperti halnya lembaga-lembaga negara yang membutuhkan hubungan baik dengan para aparatur negara. Hubungan yang baik antar lembaga negara dengan aparatur negara diharapkan mampu mewujudkan pemerintahan yang baik.

Prinsip selanjutnya tranparansi dalam hal penyelenggaraan pemerintahan merupakan salah satu prinsip yang harus dipegang oleh suatu negara demi bisa mewujudkan pemerintahan yang baik. 
Intinya, keterbukaan terhadap informasi merupakan hal yang amat memengaruhi tata kelola pemerintah. Dengan adanya transparansi dalam hal penyelenggaraan pemerintahan, membuat masyarakat luas dapat dengan bebas memberikan kritik terhadap kinerja pemerintahan. Hal ini diharapkan mampu memberikan feedback bagi kinerja pemerintahan untuk dapat lebih baik lagi dalam memajukan negara.

Prinsip berikutnya yang harus diterapkan oleh suatu negara demi mewujudkan pemerintahan yang baik ialah adanya partisipasi warga negara yang tinggi. Jadi, peran tiap-tiap warga negara sangat dibutuhkan demi mewujudkan pemerintahan yang baik. Adapun peran serta warga negara yang baik tentu akan memberikan dampak yang baik berupa terkendalinya serta keberpihakan kepada kepentingan masyarakat luas. Jadi, bukan hanya pemerintahan saja yang memiliki lakon dalam mewujudkan pemerintahan yang baik melainkan tiap-tiap warga negara pun bisa ikut berpartisipasi.

Prinsip berikutnya yang wajib diterapkan oleh suatu negara untuk merealisasikan pemerintahan yang baik ialah dengan mengalokasikan sumber daya yang baik. Sumber daya yang dialokasikan dengan baik tersebut adalah masyarakat itu sendiri. Istilahnya, sumber daya yang dimiliki oleh suatu negara tersebut merupakan harta karun bagi negara tersebut. Dengan demikian dapat diartikan bahwa pengalokasian sumber daya yang baik tentu akan memberikan dampak baik bagi tata kelola dari pemerintahan yang baik pula.

Prinsip berikutnya yang harus diterapkan bagi negara yang ingin merealisasikan pemerintahan yang baik ialah adanya kejelasan terkait tanggung jawab pemerintah. Jadi, ketika pemerintah telah melakukan suatu kinerja maka pemerintah harus sudi dikritik dan dievaluasi oleh masyarakat luas demi memperbaiki kinerja yang lalu. Sebagai contoh nyata adalah anggota Dewan Perwakilan Rakyat Daerah (DPRD). Sebagai dewan yang mengaku pilihan hati nurani rakyat, sudah sewajarnya mereka yang disebut sebagai dewan harus sudi menerima evaluasi, kritik dan aspirasi rakyat. Bukan lantas mempermainkan posisi yang mereka jabat saat ini demi kepentingan pribadi dan sekutunya saja tanpa adanya keberpihakan dengan rakyat itu sendiri.

Prinsip terakhir dalam upaya mewujudkan pemerintahan yang baik dalam hal tata kelola pemerintahan ialah tingginya orientasi terhadap tujuan yang sama. Jadi, dengan adanya orientasi terhadap tujuan bersama yang tinggi bisa menyebabkan meningkatnya persatuan dan kesatuan seluruh masyarakat di negara Indonesia ini.

\section{HASIL DAN PEMBAHASAN}

\section{Fungsi Manajemen}

George R. Terry, 1958 dalam bukunya Principles of Management (Sukarna, 2011: 10) membagi empat fungsi dasar manajemen, yaitu planning (perencanaan), organizing (pengorganisasian), actuating (pelaksanaan) dan controlling (pengawasan). Keempat fungsi manajemen ini disingkat dengan POAC.

\section{Planning (Perencanaan)}

George R. Terry mengemukakan tentang planning sebagai berikut.

"Planning is the selecting and relating of facts and the making and using of assumptions regarding the future in the visualization and formulation to proposed of proposed activation believed necessary to accieve desired result". (Perencanaan adalah pemilih fakta dan penghubungan fakta-fakta serta pembuatan dan penggunaan perkiraan-perkiraan atau asumsi-asumsi untuk masa yang akan datang dengan jalan menggambarkan dan merumuskan kegiatan-kegiatan 
yang diperlukan untuk mencapai hasil yang diinginkan).

\section{Organizing (Pengorganisasian)}

Pengorganisasian tidak dapat diwujudkan tanpa ada hubungan dengan yang lain dan tanpa menetapkan tugastugas tertentu untuk masing-masing unit. George R. Terry (dalam Sukarna, 2011: 38) mengemukakan tentang organizing sebagai berikut.

"Organizing is the determining, grouping and arranging of the various activities needed necessary for the attainment of the objectives, the assigning of the people to thesen activities, the providing of suitable physical factors of environment and the indicating of the relative authority delegated to each respectives activity. (Pengorganisasian ialah penentuan, pengelompokan, dan penyusunan macam-macam kegiatan yang diperlukan untuk mencapai tujuan, penempatan orang-orang (pegawai), terhadap kegiatan-kegiatan ini, penyediaan faktor-faktor fisik yang cocok bagi keperluan kerja dan penunjukan hubungan wewenang, yang dilimpahkan terhadap setiap orang dalam hubungannya dengan pelaksanaan setiap kegiatan yang diharapkan).

\section{Actuating (Pelaksanaan/Penggerak- an)}

Menurut George R. Terry (dalam Sukarna, 2011: 82):

"Actuating is setting all members of the group to want to achieve and to strike to achieve the objective willingly and keeping with the managerial planning and organizing efforts" (Penggerakan adalah membangkitkan dan mendorong semua anggota kelompok agar supaya berkehendak dan berusaha dengan keras untuk mencapai tujuan dengan ikhlas serta serasi dengan perencanaan dan usaha-usaha pengorganisasian dari pihak pimpinan).

\section{Controlling (Pengawasan)}

Menurut George R. Terry (dalam Sukarna, 2011: 110) controlling, yaitu:

"Controlling can be defined as the process of determining what is to accomplished, that is the standard, what is being accomplished. That is the performance, evaluating the performance, and if the necessary applying corrective measure so that performance takes place according to plans, that is conformity with the standard". (Pengawasan dapat dirumuskan sebagai proses penentuan apa yang harus dicapai yaitu standard, apa yang sedang dilakukan yaitu pelaksanaan, menilai pelaksanaan, dan bila mana perlu melakukan perbaikanperbaikan, sehingga pelaksanaan sesuai dengan rencana, yaitu selaras dengan standar (ukuran)).

Pengawasan mempunyai peranan atau kedudukan yang penting sekali dalam manajemen, mengingat mempunyai fungsi untuk menguji apakah pelaksanaan kerja teratur tertib, terarah atau tidak. Dengan demikian control mempunyai fungsi untuk mengawasi segala kegiatan agar tertuju kepada sasarannya, sehingga tujuan yang telah ditetapkan dapat tercapai.

Fungsi pengawasan DPRD pada intinya dilakukan oleh alat kelengkapan DPRD yang kita kenal nama Komisi-komisi di DPRD. Untuk DPRD Kota Depok ada 4 Komisi, yakni terdiri dari:

1. Komisi A membidangi urusan pemerintahan

2. Komisi B membidangi urusan perekonomian dan keuangan daerah

3. Komisi C membidangi urusan Pembangunan

4. Komisi D membidangi urusan Kesejahteraan rakyat 
Komisi-komisi ini merupakan alat kelengkapan wajib sifatnya seluruh anggota DPRD masuk di dalam alat kelengkapan ini. Berbeda dengan alat kelengkapan lainnya, seperti Badan Anggaran, Badan Musyawarah, Badan Pembentukan Peraturan Daerah, dan Badan Kehormatan Daerah dan lainlainnya. Termasuk Panitia Khusus (pansus) maka untuk alat perlengkapan yang lain anggota DPRD tidak wajib masuk ke alat perlengkapan tersebut. Akan tetapi, setiap anggota DPRD tanpa kecuali wajib atau berhak untuk masuk salah satu dari alat kelengkapan yang dikenal dengan nama komisi. Tentunya dikecualikan adalah unsur Pimpinan DPRD di mana unsur pimpinan DPRD menjadi koordinator dari salah satu komisi yang ada. Dan dia juga jadi bagian komisi, maka itu bahwa Fungsi Pengawasan adalah fungsi yang paling penting dan paling mendasar di dalam lembaga DPRD adalah di mana tidak seperti halnya Fungsi Pembentukan Peraturan Daerah, Fungsi pembahasan dalam Pansus, Fungsi Anggaran, dan dalam Badan Anggaran, Fungsi pengawalan norma dan kode etik anggota dalam Badan Kehormatan, Fungsi Koordinasi dalam Badan Musyawarah, dan lainnya.

Maka untuk Fungsi Pengawasan setiap anggota DPRD wajib menjalankan fungsi pengawasan tersebut. Sehingga menunjukkan bahwa fungsi pengawasan adalah fungsi yang paling penting, dan paling mendasar hakiki dari keberadaan Lembaga DPRD. Maka bagaimana mekanisme fungsi pengawasan ini dijalankan oleh DPRD lewat alat kelengkapan yang disebut dengan komisi, maka komisi-komisi ini kemudian diatur pembagian urusannya, ada 4 secara besar maka dibagi lagi urusan-urusan yang terkait bidang tersebut. Dan pembagian urusan pemerintahan, dan ada pembagian berdasarkan Organisasi Perangkat Daerah (OPD) yang menjadi mitra setiap komisi. Maka setiap komisi tertentu punya urusan Pemerintahan Daerah bidang tertentu dan juga punya mitra kerja berupa OPD, Dinas, Badan, Kantor dll. Ada dibawa Pemerintahan Daerah, DPRD melalui komisi ini melakukan serangkaian kegiatan pengawasan apa saja yang diawasi, yang diawasi adalah pelaksanaan Peraturan Daerah dan Pelaksanaan APBD, di mana peraturan daerah dan APBD merupakan produk hukum dan produk anggaran yang sudah hasilkan oleh pemerintahan daerah dalam hal ini kepala daerah bersama dengan DPRD. Fungsi Pengawasan DPRD ini dilakukan dengan mengacu pada peraturan daerah dan APBD tersebut. Bagaimana peraturan daerah tersebut dilaksanakan, bagaimana anggaran tersebut dilaksanakan, kemudian dilakukanlah serangkaian rapat-rapat antara komisi-komisi dengan OPD terkait maupun dalam bentuk Sidak, Inspeksi Mendadak ke lapangan, Menerima Pengaduan dari masyarakat, atau memantau langsung di lokasi-lokasi pelayanan pemerintahan, lokasi-lokasi pembangunan, lokasi-lokasi di mana berbagai hayat hidup warga dikelola dan dijalani oleh pemerintah. Kemudian DPRD melakukan Pengawasan, pengawasan ini dilakukan secara aktif maupun responsif. Aktif di mana DPRD melakukan tinjauan kelapangan, dan berbagai kantor-kantor pemerintah, tempat-tempat keluarga melihat secara langsung pelaksanaan-pelaksanaan Perda maupun APBD tersebut termasuk pelayanan pemerintahan yang dikelola oleh pemerintah daerah. Dan hasil pengawasan inilah DPRD melakukan berbagai tidak lanjut, dalam bentuk rapat-rapat Evaluasi, rapat-rapat koordinasi dengan OPD dan Kepala Daerah, kemudian melakukan koreksi-koreksi, teguran-teguran, atau juga melakukan evaluasi dan melakukan dorongan-dorongan untuk perbaikan Perda selanjutnya, melakukan perbaikan APBD selanjutnya dan sebagainya.

Kemitraan ini merupakan kemitraan terpenting dari keseluruhan kerja DPRD di mana komisi menjadi ujung tombaknya. Oleh karena itu, setiap anggota DPRD 
wajib memahami fungsi pengawasan ini dan memaksimalkan fungsi ini dalam rangka kesejahteraan masyarakat. Dan juga perbaikan kinerja pemerintah daerah.

\section{Fungsi Pembentukan Perda}

\section{- Proses Legislatif Kepala Daerah dan Dewan Perwakilan Rakyat Daerah DPRD dalam pembentukan peraturan daerah (Perda)}

Berbicara tentang pemerintahan daerah dalam konstitusi disebutkan bahwa Negara Kesatuan Republik Indonesia (NKRI) itu terdiri atas provinsi dan provinsi itu terbagi atas kabupaten/kota dan setiap pemerintah kabupaten/kota itu ada pemerintahan daerahnya di mana ada unsur pemerintah Daerah dan ada DPRD dan kalo bicara pemerintah daerah salah satu bagiannya adalah kepala daerah ini dipilih lewat pemilihan kepala daerah kemudian sementara DPRD-nya pilih lewat pemilih.

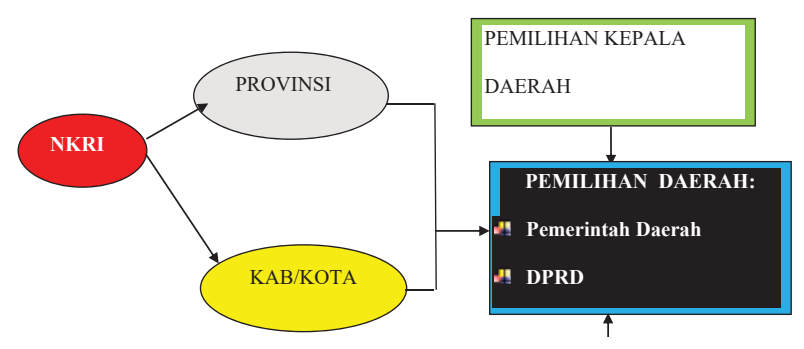

\section{Gambar 2}

Pemerintahan Daerah

Berdasarkan UU No. 23 Tahun 2014 pemerintah daerah adalah penyelenggaraan urusan pemerintahan oleh Pemerintah Daerah dan DPRD. Menurut asas otonomi dan tugas pembantuan. Dengan prinsip otonomi seluas-luasnya. Dalam sistem dan prinsip Negara Kesatuan Republik Indonesia sebagaimana yang dimaksud dalam UUD 1945.

Lebih lanjut UU No. 23 Tahun 2014 adalah Pemerintah Daerah itu Kepala Daerah sebagai unsur penyelenggara Pemerintahan Daerah. Memimpin pelaksanaan urusan pemerintahan yang menjadi kewenangan daerah otonom. Lalu kemudian di situ juga dikatakan bahwa DPRD adalah Lembaga Perwakilan Rakyat Daerah, berkedudukan sebagai unsur penyelenggara Pemerintahan Daerah. Unsur penyelenggara pemerintahan Daerah sehingga hubungan kerja antara kepala daerah dengan DPRD dalam bahasa UU adalah Kemitraan yang sejajar. Kemitraan sejajar itu maksudnya bahwa diwujudkan dalam bentuk persetujuan bersama dalam pembentukan peraturan daerah dalam hal penyampaian laporan keterangan pertanggungjawaban kepada DPRD diwujudkan dalam bentuk persetujuan terhadap kerja sama yang akan yang akan dilakukan oleh pemerintah daerah, dan diwujudkan rapat konsultasi DPRD kepada kepala daerah secara berkala. Namun kita pahami bersama bahwa laporan pertanggungjawaban itu tidak dapat dijadikan sebagai sarana di dalam pemberhentian kepala daerah, tidak dapat dijadikan sarana pemberhentian kepala daerah.

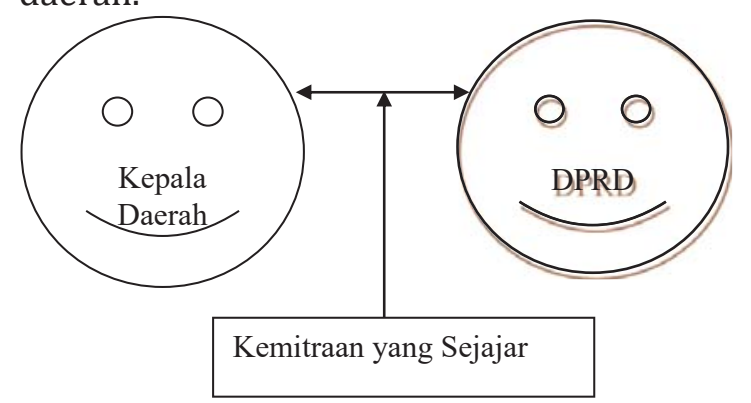

Gambar 3

Hubungan antara DPRD dan Kepala Daerah

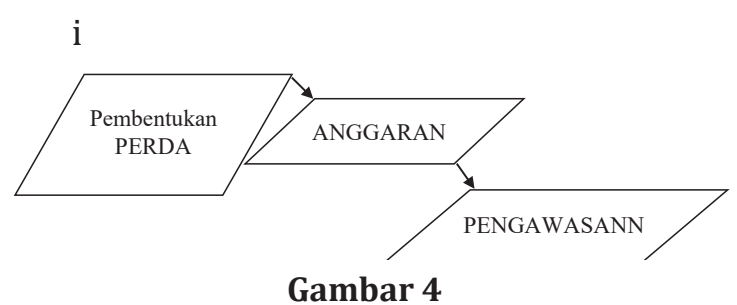

Fungsi Pengawasan DPRD

Pembentukan Perda DPRD berbicara dengan gubernur atau bupati/wali kota apakah menyetujui atau tidak menyetujui rancangan peraturan daerah. Bisa tidak 
menyetujui. Mengajukan usulan rancangan Perda dalam kontes Gubernur atau bupati/ wali kota kalo di kabupaten/kota. Kemudian mengusung program pembentukan daerah bersama Gubernur atau bersama bupati/ wali kota kalo di kabupaten/kota di mana tentu kalo bicara bicara penyusunan program pembentukan Perda itu memuat daftar urutan dan prioritas rancangan peraturan daerah dalam satu tahun anggaran. Dan dalam menetapkan DPRD melakukan koordinasi dengan Gubernur atau Wali kota/ bupati.

\section{Fungsi Anggaran}

Kemudian Fungsi ANGGARAN Ini berkaitan dengan persetujuan bersama terhadap RAPerda tentang APBD yang diajukan oleh Gubernur atau Bupati/ Wali kota, tentu fungsi anggaran yang dilaksanakan ini dengan cara ada empat, yaitu:

1. Membahas kriteria umum anggaran dan PPAS yang disusun oleh Gubernur atau bupati/wali kota berdasarkan RKPD

2. Membahas tentang RAPBD tentang ABPD

3. Kemudian membahas RAPBD tentang perubahan APBD atau membahas tentang pertanggungjawaban APBD.

\section{Fungsi Pengawasan}

Fungsi pengawasan hal-hal apa saja yang dilakukan dalam konteks pengawasan ini yaitu diwujudkan dalam bentuk pengawasan terhadap pelaksanaan peraturan daerah dan peraturan Gubernur atau peraturan Bupati/ Wali kota sesuai dengan tingkatannya. Kemudian mengawasi pelaksanaan peraturan perundang-undangan lain yang terkait dengan penyelenggaraan pemerintahan daerah. Kemudian pengawasan terhadap pelaksanaan tidak lanjut hasil pemeriksaan laporan keuangan oleh BPK.
Kemudian Hak DPRD adalah....

\section{a. Hak Interpelasi}

Hak DPRD untuk meminta keterangan kepada Gubernur atau bupati/wali kota mengenai kebijakan pemerintah daerah yang penting dan strategis serta berdampak luas kepada berkehidupan bermasyarakat dan bernegara.

\section{b. Hak Angket}

Hak DPRD untuk melakukan penyelidikan terhadap kebijakan yang penting dan strategis dan berdampak luas yang diduga bertentangan dengan ketentuan perundang-undangan. (kita kembali ke hierarki bahwa setiap aturan tidak boleh bertentangan).

\section{c. Hak Menyatakan Pendapat}

Hak menyatakan pendapat adalah hak DPRD menyatakan pendapat terhadap kebijakan atau sebagai tidak lanjut hak Interpelasi dan hak angket.

\section{- Alat Kelengkapan DPRD}

1. Pimpinan

2. Badan Musyawarah

3. Komisi

4. Badan pembentukan Perda

5. Badan anggaran

6. Badan kehormatan dan

7. Alat kelengkapan lainnya yang diperlukan dan dibentuk oleh rapat paripurna.

Maka satu fungsi pengawasan DPRD adalah Badan Pembentukan Peraturan Daerah yang mengurusi peraturan daerah adalah Badan Pembentukan Peraturan Daerah. Maka yang menjadi kewenangan dari kepala daerah:

a. Mengajukan Raperda

b. Menetapkan Perda yang telah mendapat persetujuan bersama DPRD

c. Menetapkan Perkada dan keputusan kepala daerah 
d. Mengambil tindakan tertentu dalam keadaan mendesak yang sangat dibutuhkan oleh Daerah dan/atau masyarakat.

Tahapan Pembentukan peraturan daerah adalah:

a. Untuk menyelenggarakan otonomi daerah dan tugas pembantuan, Daerah Membentuk Peraturan Daerah

b. Perda dibentuk oleh DPRD dengan persetujuan bersama Kepala Daerah.

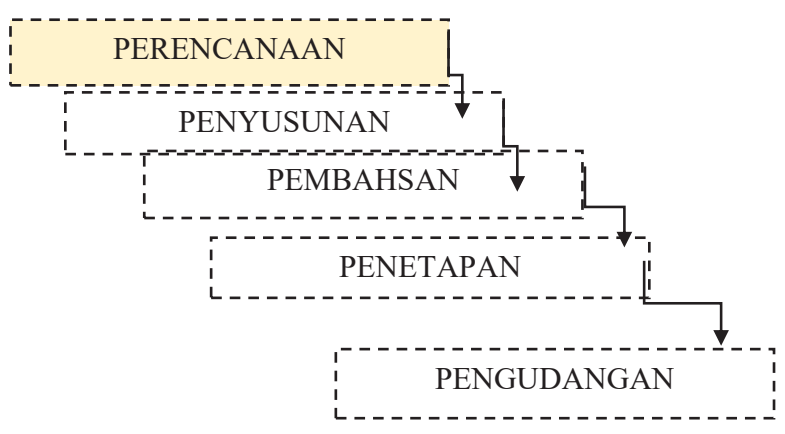

Gambar 5

Tahapan-tahapan proses pembentukan Perda

Dengan demikian perencanaan Perda adalah:

a. Perencanaan penyusunan Perda dilakukan dalam program pembentukan Perda.

b. Disusun oleh DPRD dan Kepala Daerah untuk jangka waktu satu tahun berdasarkan skala prioritas pembentukan Raperda

c. Ditetapkan keputusan DPRD.

d. Dilakukan sebelum penetapan Raperda tentang APBD.

Dalam pembentukan program Raperda dapat dimuat namanya daftar kumulatif terbuka yang terdiri atas akibat keputusan Mahkamah Agung, kemudian APBD dan pernyataan kecamatan kemudian pernyataan Desa artinya DPRD atau Kepala Daerah dapat mengajukan Raperda di luar program pembentukan Perda dengan alasan ada penekanan DPRD dan Kepala Daerah bisa mengajukan Raperda di luar program tadi dengan alasan sebagai berikut.

1. Mengatasi keadaan luar biasa dan keadaan konflik atau bencana alam (tidak terduga)

2. Menindaklanjuti tidak kerja sama dengan pihak lain.

3. Mengatasi keadaan tertentu lainnya yang sangat urgen.

4. Akibat pembatalan oleh menteri oleh Perda untuk Perda provinsi oleh Gubernur wakil pemerintah pusat untuk Perda Kabupaten/kota (akibat Pembatalan)

5. Berdasarkan perintah dari ketentuan peraturan undang-undang yang lebih tinggi dan setelah pembentukan program Perda ditetapkan.

Maka bisa saja kemudian ditetapkan program pembentukan Perda tiba-tiba kemudian ada aturan baru yang keluar yang memerintahkan untuk membuat ketentuanketentuan khusus yang dimuat dalam Perda. Kemudian rancangan Perda bisa saja diusulkan, baik oleh DPRD maupun oleh Kepala Daerah.

Kemudian selanjutnya adalah penyusunan Perda terdiri dari:

a. Penyusunan Raperda dilakukan berdasarkan program pembentukan peraturan daerah

b. Penyusunan Raperda dapat berasal dari DPRD atau Kepala Daerah.

c. Penyusunan Raperda berpedoman pada ketentuan peraturan perundangundangan.

Kemudian dilanjutkan dengan Pembahasan Perda tersebut:

a. Dilakukan oleh DPRD bersama Kepala Daerah untuk mendapat persetujuan bersama.

b. Pembahasan bersama dilakukan melalui tingkat pembicaraan. 
c. Tingkat-tingkat pembicaraan dilakukan dalam:

- Rapat komisi/panitia/badan/alat kelengkapan DPRD yang khusus menangani pembentukan Perda.

- $\quad$ Rapat paripurna.(untuk mengambil keputusan)

Maka tidak bisa disetujui bersama oleh DPRD dan Kepala Daerah lalu Undang-undang Perda itu berlaku. Tetapi, menurut UU No. 23 Tahun 2014 bahwa Raperda baik dari Kepala Daerah maupun DPRD dibahas bersama, lalu disetujui bersama, maka Raperda itu harus mendapatkan nomor registrasi. Kalo Raperda dari provinsi tentu mendapatkan persetujuan dari menteri. Kemudian kalo Raperda dari Kabupaten/kota oleh Gubernur sebagai wakil pemerintah pusat. Raperda yang belum mendapatkan nomor registrasi belum dapat ditetapkan oleh kepala daerah dan belum dapat diundang-undangkan dalam lembaran daerah. Gubernur sebagai wakil pemerintah pusat secara berkala menyampaikan laporan peraturan daerah kabupaten/kota yang telah mendapatkan nomor registrasi kepada menteri.

Untuk menjaga teorinya Hans Kelsen Bahwa setiap aturan itu harus sesuai dengan aturan yang lebih tinggi dan aturan itu bersifat statis dalam artian norma itu tidak boleh bertentangan dengan satu sama lain.

Sehingga penetapan peraturan daerah tersebut bahwa rancangan peraturan daerah tersebut sebenarnya telah disetujui bersama oleh Kepala Daerah dan DPRD dan disampaikan kepada pimpinan DPRD kepada Kepala Daerah untuk ditetapkan Perda itu tiga hari setelah disetujui wajib menyampaikan Raperda untuk untuk mendapat nomor registrasi Raperda itu masing-masing tiga hari. Kemudian Menteri memberikan Raperda Provinsi Menteri memberikan registrasi nomor Raperda Provinsi Gubernur sebagai wakil pemerintah pusat daerah memberikan nomor registrasi terhadap Raperda Kabupaten/kota paling lambat tujuh hari, sejak Raperda itu diterima. Rancangan peraturan daerah yang dapat nomor registrasi ditetapkan oleh Kepala Daerah bukan tanda tangan maksimal tiga puluh hari dalam hal Kepala Daerah tidak menandatangani Raperda yang telah dapat nomor registrasi maka Raperda tersebut menjadi sah menjadi Perda dan wajib diundangkan dalam lembaran daerah. Berbeda dengan UU, yakni Presiden dan DPR sudah setuju walaupun Presiden dan DPR belum tanda tangani langsung sah

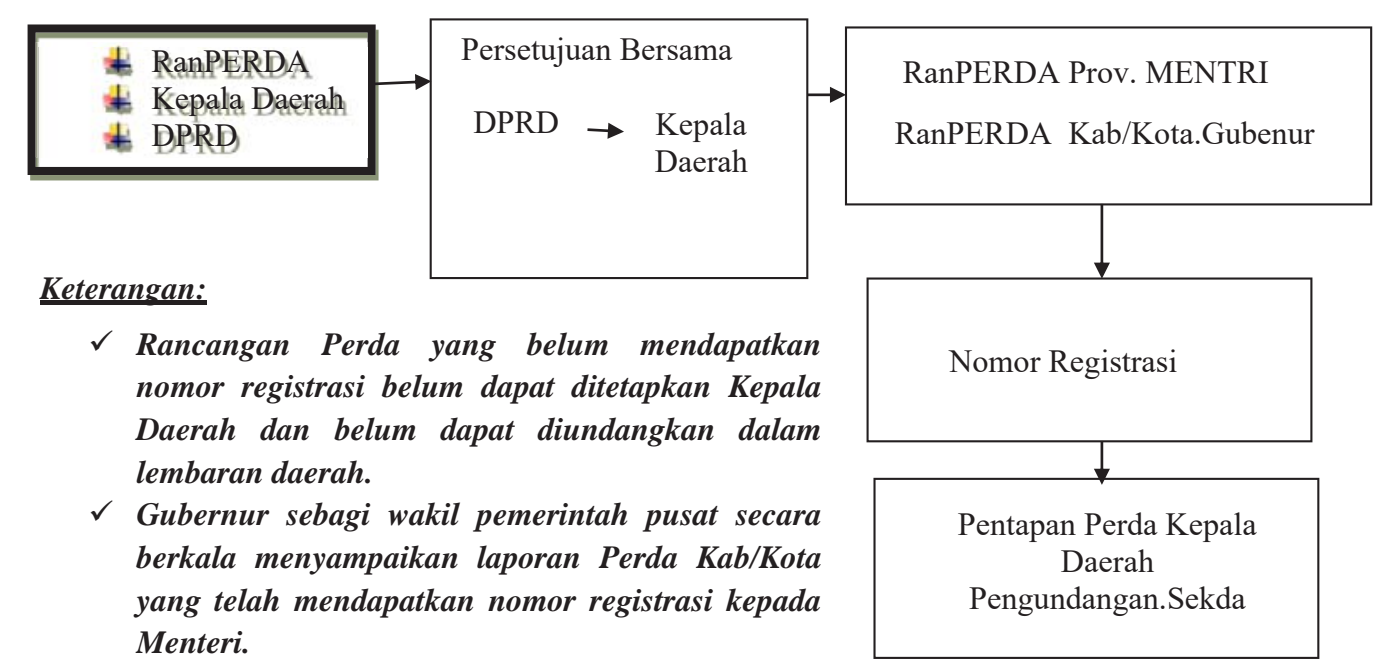

Gambar 6

Tahapan-tahapan proses penetapan Perda 
dan bisa berlaku UU tersebut. Kalau Raperda setelah dapat nomor registrasi baru bisa diundang-undangkan.

Selanjutnya adalah pengundangan Perda terdiri atas:

a. Peraturan perundang-undangan yang diundangkan dalam lembaran daerah adalah Perda Provinsi dan Perda Kabupaten/kota.

b. Peraturan Gubernur dan peraturan Bupati/Wali kota diundangkan dalam berita Daerah.

c. Pengundangan peraturan perundangundangan dalam Lembaran Daerah dan Berita Daerah dilaksanakan oleh Sekretaris Daerah (Sekda).
Karena ini banyak yang menyampaikan kenapa Eksekutif, kenapa bukan di Legislatif aja atau di DPRD tapi itu tentu ada pertimbangan-pertimbagan dan dikaji lebih jauh.Kemudian setelah ditetapkan ada evaluasi terhadap Raperda sebagaimana melakukan evaluasi dan sebelum memberikan nomor registrasi tentu ada EVALUASI.

Bukan persoalan suka dan tidak, bukan kedekatan hubungan antara Bupati/Wali kota dan Gubernur atau Gubernur dengan Menteri didasarkan pada Evaluasi Perda, apakah Raperda itu tidak bertentangan dengan Rancangan Pembangunan Jangka Panyang Daerah (RPJPD) Rancangan Pembangunan Jangka Menengah Daerah

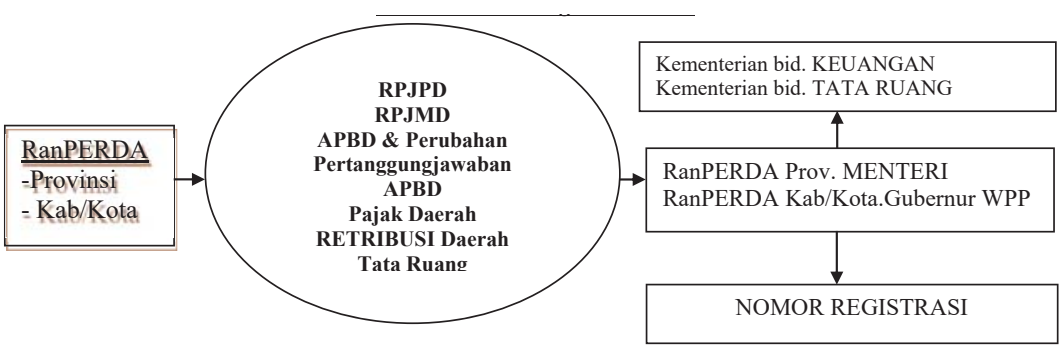

Gambar 7

Evaluasi Rancangan Perda

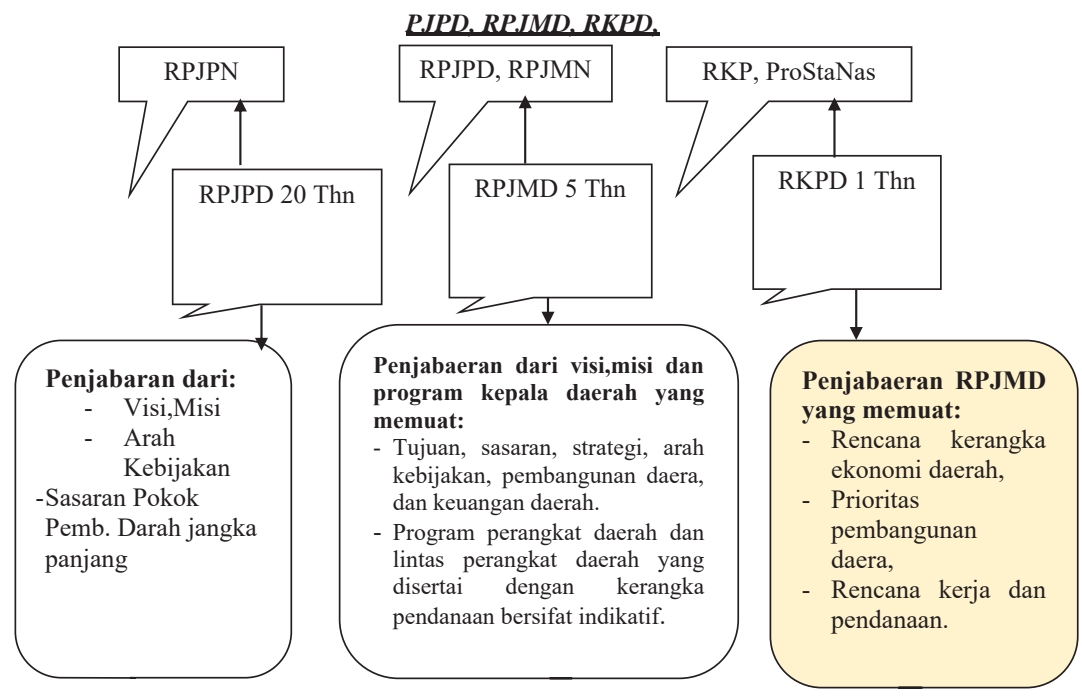

Gambar 8

RJPD, RPJMD, dan RKPD 
(RPJMD) Kemudian APBD dan perubahan pertanggungjawaban APBD, pajak daerah, retribusi daerah, tata ruang. menjadi pertimbangan-pertimbangan kemudian untuk melahirkan nomor registrasi.

Pembatalan Peraturan Daerah dan Peraturan Kepala Daerah bisa saja dibatalkan, kalo bertentangan dengan aturan yang di atas atau hal-hal yang umum pertentangan dengan hal-hal yang berkaitan dengan kesusilaan maka bisa saja dibalikkan (tidak diberi nomor registrasi). Kalo tetap diberlakukan maka ada saksi tertulis. Namun tetap diberlakukan dan ada mekanisme keberatan bisa dibahas UU lebih lanjut.
Bahwa Kepala Daerah membatalkan pelaksanaan Perkada itu idealnya. Kalo tidak maka ada banyak sanksi yang menanti. Bisa aja terkait dengan saksi Administrasi Keuangan, Sanksi memberikan pelatihan, untuk mengetahui tentang hal-hal yang berkaitan dengan peraturan perundang-undangan. Akar menjaga aturan perundang-undangan itu berapa pada susunan Hierarkis sehingga aturan perundang-undangan sebagai instrumen untuk melakukan pencapaian tujuan itu bisa seiring, sejalan, dengan aturan yang lebih tinggi pada sampai konstitusi kita.

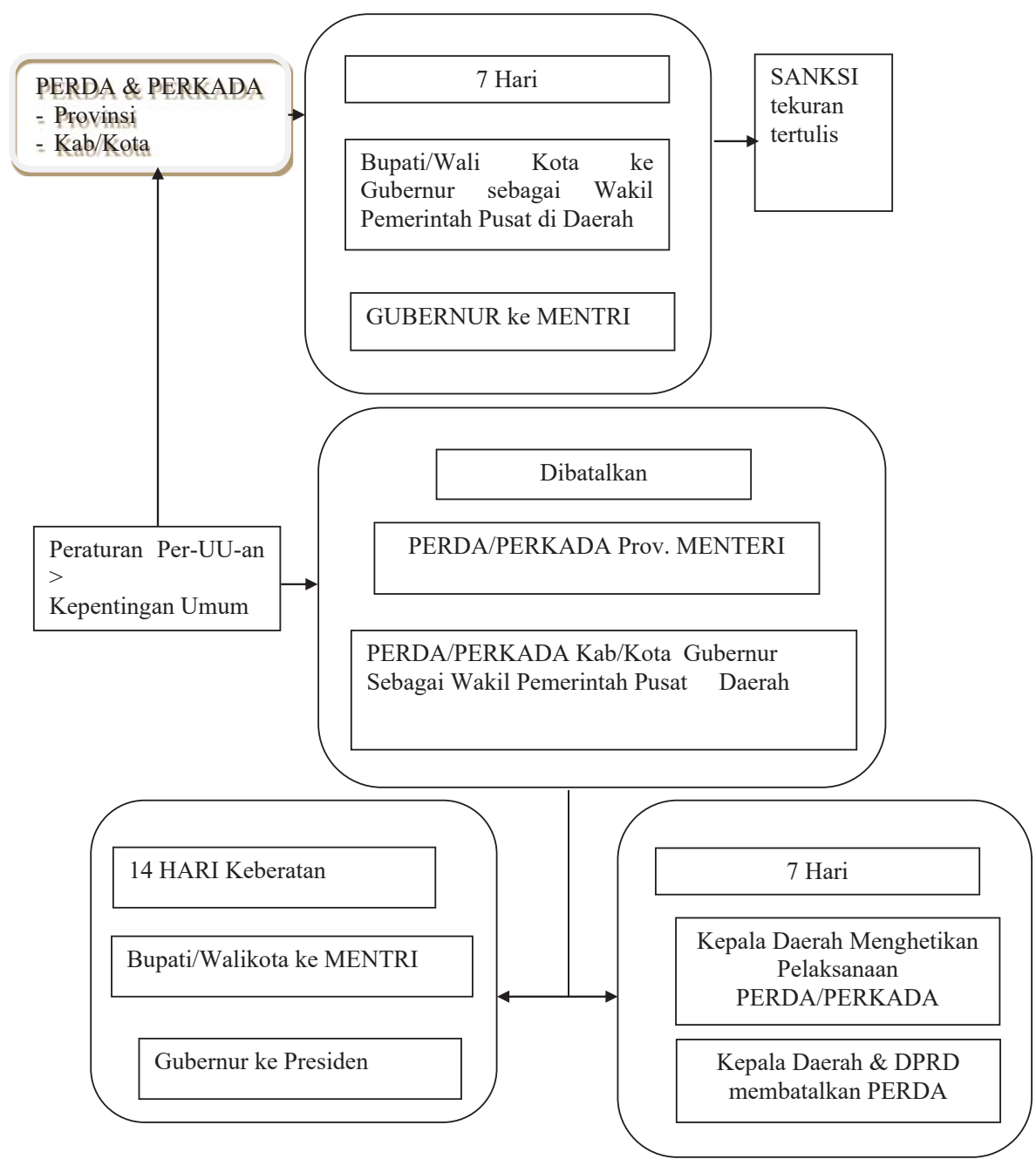

Gambar 9

Pembatalan Peraturan Daerah dan Peraturan Kepala Daerah 


\section{Kedudukan DPRD dalam Penyeleng- gara Pemerintah Daerah}

\section{- Pengaturan DPRD}

DPRD itu merupakan bagian dari unsur pemerintah yaitu dia berada dibawa struktur Eksekutif walaupun secara fungsi dia punya kedudukan atau dia menjalankan fungsi legislasi/Eksekutif di daerah maka DPRD itu merupakan bagian dari pemerintah daerah dibawa naungan presiden.

Secara konstitusional DPRD disebutkan atau diatur di dalam Pasal 18 ayat (3) UUD Negara Republik Indonesia Tahun 1945 (perubahan) di dalam pasal tersebut disebutkan bahwa pemerintahan daerah provinsi, daerah kabupaten, dan kota memiliki Dewan Perwakilan Rakyat Daerah yang anggota-anggotannya, dipilih melalui pemilihan umum. Dan pengaturan pemilihan umum DPRD juga disebutkan di dalam pasal khusus mengenai pemilihan umum yaitu di Pasal 22 E ayat (2) dan (3) UUD Negara Republik Indonesia Tahun 1945 (perubahan). Selanjutnya tata cara pengaturan catacara penyelenggaraan pemerintah daerah itu diatur dalam UU termasuk DPRD maka tataran UU itu DPRD diatur di mana? Sebelum lahirnya UU No. 23 Tahun 2014 tentang Pemerintah Daerah, pengaturan mengenai DPRD diatur di dalam UU No. 17/2014 tentang MPR, DPR, DPD dan DPRD atau sering kita kenal (UU MD3). Sebelum ada UU No. 23 Tahun 2014 DPRD diatur di dalam UU tersebut. Namun karena untuk mempertahankan konsep bahwa DPRD merupakan bagian dari Pemerintah Daerah, maka ketentuan mengenai DPRD ditarik ke dalam UU No. 23 Tahun 2014 tentang Pemerintahan Daerah berdasarkan Pasal 409 huruf d dinyatakan bahwa pasalpasal yang berkaitan dengan DPRD dalam UU No. 17/2014 tentang MD3 dicabut dan dinyatakan tidak berlaku. Artinya, kita memiliki mengenai DPRD landasan hukum yang digunakan bukan MD3 lagi. Tetapi, yang digunakan landasan hukum tentang mengenai DPRD adalah UU No. 23 Tahun 2014 dan juga perubahannya.

Untuk me-review ulang maka kita lihat Pemerintahan Daerah itu ada dua unsur pelaksana atau penyelenggara

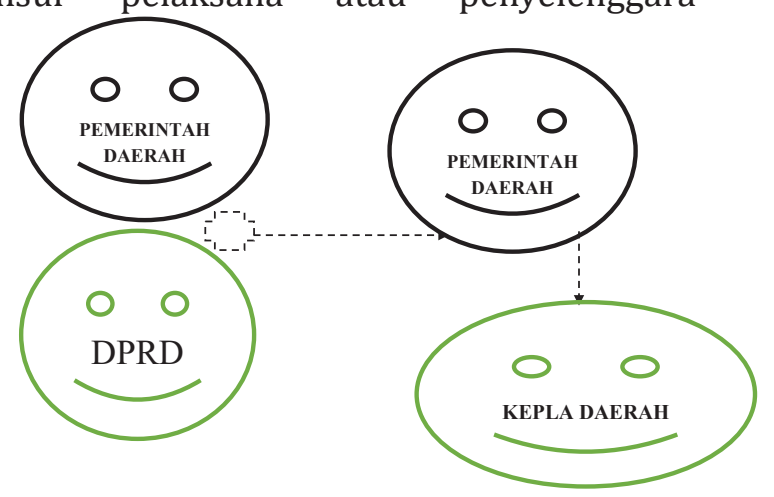

Gambar 10

Gambar Lembaga Pemerintah Daerah Menurut Pasal 1 angka 2 UU 23/2014

Hubungan kerja antara DPRD dan Kepala Daerah (Pasal 207 UU No. 23/2014) Hubungan kerja didasarkan atas kemitraan yang sejajar, dan bentuk hubungan kemitraannya terdiri dari:

a. Persetujuan bersama dalam pembentukan Perda;

b. Penyampaian laporan keterangan pertanggungjawaban kepada DPRD (tidak sebagai sara pemberhentian kepala daerah)

c. Persetujuan terhadap kerja sama yang akan dilakukan pemda;

d. Rapat konsultasi DPRD dengan kepala daerah secara berkala; dan

e. Bentuk lainnya sesuai dengan ketentuan peraturan perundang-undangan. (terkait hak DPRD)

Apa saja bentuk kerja sama dengan antara DPRD dengan Kepala Daerah karena dalam kedudukannya dia adalah sejajar dan sifat hubungannya, Kemitraan bentuk kemitraannya terdiri dari persetujuan bersama dalam pembentukan Perda kemudian penyampaian laporan keterangan pertanggungjawaban DPRD di mana pertangggungjawaban DPRD ini bukan 
menjadi atau tidak sebaliknya menjadi sarana pemberhentian kepala daerah. Kenapa? Karena kepala daerah saat ini dilaksanakan dan dipilih melalui pemilihan umum atau melalui ketentuan yang diatur di dalam UU pemerintah daerah yang khusus atau Istimewa. Misalnya, daerah istimewa jogjakarta dipilih melalui berdasarkan tahtah. Apakah? DPRD bisa menurunkan atau bisa memberhentkan itu diatur UU keIstimewaan Yogyakarta.

Karena DPRD merupakan perwakilan rakyat daerah sehingga rakyat melalui perwakilan perlu tahu pemerintah daerah itu melakukan apa atau pemerintah daerah itu melakukan kerja sama dengan siapa? Inkam ke daerahnya bagaimana. DPRD secara skala diatur DPRD dan kepala daerah saling lapor untuk menyampaikan informasi apa saja sudah dilakukan kepala daerah dalam hal pembangunan daerah dan DPRD menyampaikan apa yang diperlukan oleh rakyat di daerah atau dalam hal penyusunan peraturan daerah.

Kita me-review kembali UU No. 23 Tahun 2014 berkaitan dengan bentukbentuk lainnya seperti apa. Kemudian secara definisi untuk menegaskan bahwa DPRD itu merupakan bagian dari pemerintahan daerah di dalam (Pasal 1 angka 3 UU No. 23/2014 tentang pemerintah daerah) Dewan Perwakilan Rakyat Daerah (DPRD) adalah lembaga perwakilan rakyat daerah yang berkududukan sebagai unsur penyelenggara pemerintahan daerah. Di mana mengenai keaggotaannya di dalam (Pasal 94 UU No. 23/2014 untuk provinsi, Pasal 147 UU No. 23/2014 untuk kabupaten/kota) DPRD itu terdiri atas anggota partai politik peserta pemilihan umum yang dipilih melalui umum baik untuk provinsi maupun kabupaten/ kota.

\section{- Fungsi DPRD}

Fungsi DPRD sama halnya lembagalembaga DPRD lainnya, yaitu: a. Fungsi pembentukan Perda; DPRD bersama dengan kepala daerah membahas, menyetujui/tidak menyetujui, menyusun program pembentukan Perda.

b. Fungsi Anggaran; melakukan pembahasan dan persetujuan bersama terhadap raperda APBD yang diajukan kepala daerah dan

c. Fungsi pengawasan; melakukan pengawasan terhadap pelaksanaan Perda dan Perkada, peraturan perundang-undangan yang berkaitan dengan penyelenggaraan pemerintah daerah, pelaksanaan tidak lanjut hasil pemeriksaan laporan keuangan oleh BPK

\section{- Tugas dan Wewenang DPRD}

Di dalam UU No. 9 Tahun 2015 tentang perubahan kedua UU No. 23 Tahun 2014 adalah:

a. Membentuk Perda bersama kepala daerah

b. Membahas dan memberikan persetujuan rancangan Perda

c. Melaksanakan pengawasan terhadap pelaksanaan Perda

d. Memilih kepala daerah dalam hal terjadi kekosongan jabatan untuk meneruskan sisa masa jabatan; (huruf d dihapus isinya "memilih kepala daerah") maksudnya adalah norma yang diubah melalui UU No. 9 Tahun 2015 di mana sebelumnya UU No. 23 Tahun 2014 atur atau disebutkan bahwa salah satu kewenangan dan tugas kewenangan yang tercantum di dalam huruf $b$ adalah memilih kepala daerah dan kemudian menjadi sarana pembahasan nasional banyak pro kontra sehingga pemerintah (presiden) mengeluarkan peraturan pemerintah pengganti UU No. 1 Tahun 2014 tentang pemilihan kepala daerah.

e. Mengusulkan pengangkatan dan pemberhentian kepala daerah (Gubernur melalui menteri, bupati/wali 
kota melalui gubernur) untuk mendapat pengesahan pengangkatan dan/atau pemberhentian

f. Memberikan pendapat dan pertimbangan kepada pemerintah daerah terhadap rencana perjanjian internasional di Daerah

g. Memberikan persetujuan terhadap rencana kerja sama internasional yang dilakukan oleh pemerintah Daerah

h. Meminta laporan keterangan pertanggungjawaban Kepala Daerah dalam penyelenggaraan pemerintah daerah

i. Memberikan persetujuan terhadap rencana kerja sama dengan daerah lain atau dengan pihak ketiga yang membebani masyarakat dan daerah

j. Melaksanakan tugas dan wewenang lain yang dilakukan dalam ketentuan peraturan perundang-undangan.

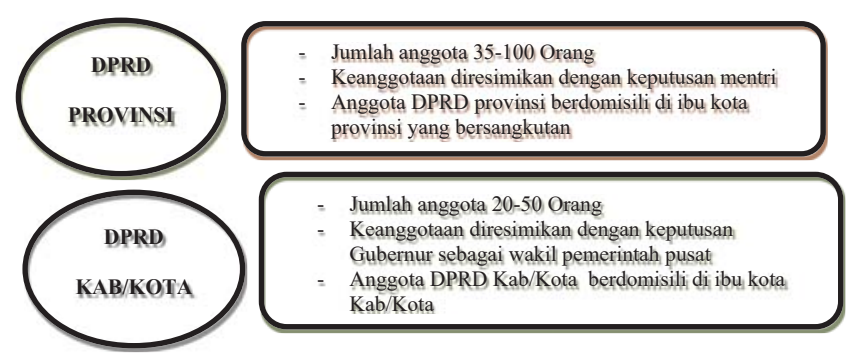

Gambar 11

Masa jabatan selama lima tahun hingga anggota DPRD yang baru mengucapkan sumpah/janji.

\section{- Fraksi dan Alat Kelengkapan DPRD}

Yang dimaksud fraksi adalah wadah berhimpunnya anggota DPRD berdasarkan anggota yang berasal dari partai atau gabungan partai.

Dan yang dimaksud dengan alat kelengkapan adalah suatu wadah atau suatu struktur yang menjalankan fungsifungsi tertentu di DPRD dan kewenangankewenangan DPRD terdiri atas: a. Pimpinan,

b. Badan Musyawarah;

c. Komisi

d. Badan pembentukan Perda

e. Badan anggaran

f. Badan kehormatan

g. Alat kelengkapan lain yang diperlukan dan dibentuk oleh rapat paripurna

Dan semua diatur lebih lanjut di dalam peraturan DPRD itu sendiri, biasanya diatur di dalam peraturan tata tertib DPRD.

Kemudian dalam menjalankan tugas, alat kelengkapan dibantu oleh sekretariat DPRD dan dapat dibantu oleh kelompok pakar/ahli.

\section{- Hak DPRD}

1. Hak Interpelasi

Hak interpelasi adalah hak DPRD untuk meminta keterangan kepada kepala daerah mengenai kebijakan pemerintah daerah yang penting dan strategis serta yang berdampak luas pada kehidupan bermasyarakat dan bernegara.

2. Hak Angket

Hak angket adalah hak untuk melakukan penyelidikan terhadap suatu kebijakan pemerintah daerah yang penting dan strategis, serta berdampak luas pada kehidupan masyarakat, daerah, dan negara yang diduga bertentangan dengan ketentuan peraturan perundangundangan. Maka hak penyelidikan ini juga bisa dihasilkan dan bisa diajukan kepada menteri dalam negeri atau bisa menjadi salah satu kelengkapan untuk apabila terjadi penyelewengan atau pelangar hukum yang dilakukan oleh pemerintah maupun unsur dalam pemerintah daerah.

3. Hak Menyatakan Pendapat

Hak menyatakan pendapat adalah DPRD menyatakan pendapat terhadap 
kebijakan kepala daerah atau mengenai kejadian luar biasa yang terjadi di daerah disertai dengan rekomendasi penyelesaiannya atau sebagai tidak lanjut pelaksanaan hak interpelasi dan hak angket.

Maka anggota DPRD hak menyatakan pendapatsesuaidenganapayanganggota DPRD diketahui sebagai anggota DPRD tentu mendapatkan pendapat didasari sesuai dengan anggota DPRD diketahui data dan dasar pemikiran secara rasional dapat dipertanggungjawabkan.

\section{Tata Kelola Pemerintahan yang Baik}

Sejatinya tata kelola pemerintahan tersebut senantiasa memiliki orientasi terhadap suatu hal yang hendak dituju, yakni untuk mencapai pemerintahan yang ideal. Adapun untuk mewujudkan orientasi tersebut, suatu negara harus senantiasa menerapkan beberapa prinsip pemerintahan yang berkesesuaian dengan UNDP di antaranya sebagai berikut.
1. Adanya kesetaraan untuk berpartisipasi dalam hal pembuatan kebijakan.

2. Kepekaan dan ketanggapan atas adanya kebutuhan stekholder.

3. Adanya kemampuan guna mediasi segala perbedaan di antara stekholder guna mencapai konsensus bersama.

4. Adanya akuntabilitas yang ditujukan untuk stekholder yang dilayani.

5. Kegiatan-kegiatan didasarkan pada kerangka hukum.

6. Adanya tranparansi dalam hal pengambilan suatu kebijakan.

7. Terdapat jaminan atas hak seluruh orang guna meningkatkan taraf hidup melalui berbagai macam cara yang adil.

8. Mempunyai visi misi yang luas dan dalam jangka waktu panjang demi keberlanjutan pembangunan sosial ekonomi yang ada.

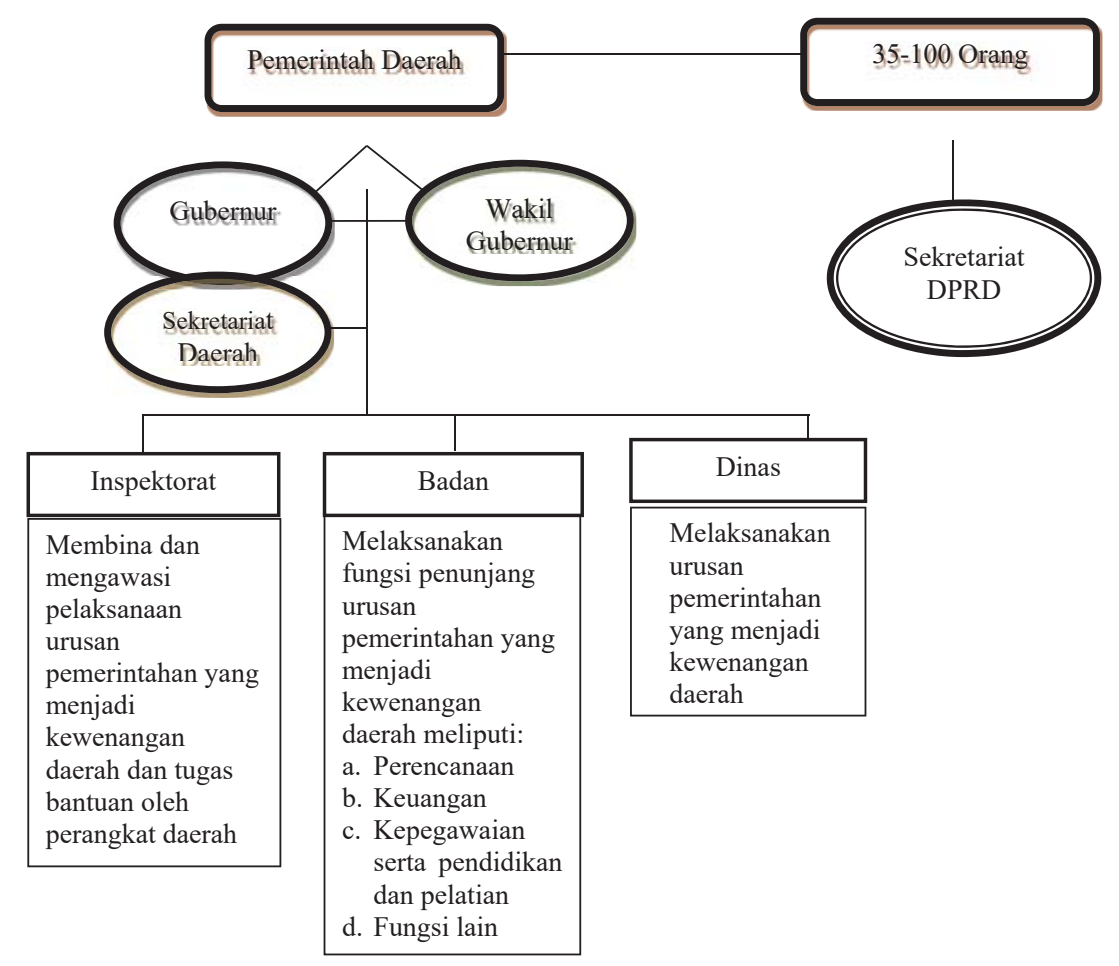

\section{Gambar 12}

Skema penyelenggara pemerintah daerah provinsi dan kabupaten/kota. 
Asas-asas umum pemerintahan sebagaimana yang dimuat dalam UU No. 28 Tahun 1998 di antaranya ialah sebagai berikut.

1. Asas kepastian hukum yang berguna untuk mengutamakan landasan peraturan undang-undang, kepatuhan maupun kebijakan penyelenggaraan negara.

2. Asas tertib penyelenggaraan negara yang berfungsi sebagai landasan keteraturan, kecocokan hingga keseimbangan pengabdian penyelenggaraan negara.

3. Asas kepentingan umum yang berfungsi untuk mendahulukan kesejahteraan umum.

4. Asas keterbukaan yang berfungsi untuk membuka diri bagi hak masyarakat untuk keperluannya serta dengan adanya jaminan perlindungan atas hak asasi mereka.

5. Asas profesionalitas yang berguna untuk mengutamakan keahlian dengan kode etik sebagai landasan utamanya.

6. Asas akuntabilitas yang berguna untuk menentukan bahwasetiap kegiatan harus senantiasa dipertanggungjawabkan kepada rakyat.

7. Asas proporsionalitas yang berguna mengutamakan keseimbangan antara hak dan kewajiban penyelenggaraan negara.

Demi mewujudkan tata kelola pemerintahan yang baik, sejatinya suatu negara harus memiliki beberapa indikator demi merealisasikan pemerintahan yang ideal tersebut:

\section{Partisipasi}

Tata Kelola Pemerintahan yang Baik adalah partisipasi dalam suatu kinerja pemerintahan, maka harus senantiasa ada evaluasi, kritik, saran maupun aspirasi dari berbagai pihak demi mewujudkan pemerintahan yang ideal.

\section{Transparansi}

Transparansi adalah indikator penting berikutnya demi mewujudkan pemerintahan yang ideal. Jadi, dengan adanya transparansi maka seluruh masyarakat bisa turut serta dalam melakukan pengawasan terhadap kinerja pemerintahan.

3. Koordinasi

Koordinasi merupakan indikator tata kelola pemerintahan yang dinilai baik, yakni dalam hal memastikan adanya keseluruhan pemangku kebijakan untuk benar-benar mempunyai kesamaan pandangan demi mewujudkan pemerintahan yang ideal. Jadi, tidak ada istilahnya pemerintahan demi kepentingan pribadi melainkan pemerintahan demi kepentingan bersama.

\section{Akuntabilitas}

Indikator akuntabilitas merupakan indikator wujud dari pertanggungjawaban atas segala peraturan yang sudah dibuat. Akuntabilitas juga dapat digunakan untuk menyimak tingkat profesionalitas tiap-tiap oknum pemerintahan dalam menyikapi adanya perbedaan.

\section{Ciri-Ciri Tata Kelola Pemerintahan yang Baik}

1. Adanya transparansi dalam hal penyelenggaraan pemerintahan bahwa tranparansi dalam hal penyelenggaraan pemerintahan merupakan salah satu prinsip yang harus dipegang oleh suatu negara demi bisa mewujudkan pemerintahan yang ideal. Intinya, keterbukaan terhadap informasi merupakan hal yang amat memengaruhi tata kelola pemerintah. Dengan adanya transparansi dalam hal penyelenggaraan pemerintahan, membuat masyarakat luas dapat dengan bebas memberikan kritik terhadap kinerja pemerintahan. Hal ini diharapkan mampu memberikan feedback bagi kinerja pemerintahan 
untuk dapat lebih baik lagi dalam memajukan negara.

2. Adanya tanggapan yang cukup baik oleh aparatur negara ketahui dalam upaya mewujudkan pemerintahan yang ideal ialah adanya tanggapan yang baik dari aparatur negara. Seperti halnya lembaga-lembaga negara yang membutuhkan hubungan baik dengan para aparatur negara. Hubungan yang baik antar lembaga negara dengan aparatur negara diharapkan mampu mewujudkan pemerintahan yang ideal.

3. Ditegakkannya supremasi hukum oleh negara ketahui sebagai prinsip tata kelola pemerintahan yang baik demi menyelenggarakan pemerintahan yang ideal ialah ditegakkannya supremasi hukum oleh negara. Supremasi yang dimaksud ialah kekuasaan hukum berikut dengan norma-norma hukum yang menjadikan dasar dari keseluruhan hal serta tetap mempunyai prinsip keadilan. Suatu negara yang memiliki orientasi untuk mewujudkan pemerintahan yang ideal tentu harus mampu menegakkan supremasi hukum. Hukum tidak boleh pandang bulu. Hukum tidak boleh pandang kasta. Sila kelima Pancasila harus ditegakkan demi mewujudkan prinsip supremasi hukum tersebut. Jika supremasi hukum dapat ditegakkan dengan baik oleh negara, maka hal tersebut akan membawa pengaruh dan efek yang baik khususnya pada tingkat keamanan maupun ketertiban di tengah masyarakat luas.

4. Adanya partisipasi warga negara yang tinggi harus diterapkan oleh suatu negara demi mewujudkan pemerintahan yang ideal ialah adanya partisipasi warga negara. Jadi, peran tiap-tiap warga negara sangat dibutuhkan demi mewujudkan pemerintahan yang ideal. Adapun peran serta warga negara yang baik tentu akan memberikan dampak yang baik berupa terkendalinya serta keberpihakan kepada kepentingan masyarakat luas. Jadi, bukan hanya pemerintahan saja yang memiliki lakon dalam mewujudkan pemerintahan yang ideal melainkan tiap-tiap warga negara pun bisa ikut berpartisipasi.

5. Adanya pengalokasian sumber daya yang baik wajib diterapkan oleh suatu negara untuk merealisasikan pemerintahan yang ideal ialah dengan mengalokasikan sumber daya yang baik. Sumber daya yang dialokasikan dengan baik tersebut adalah masyarakat itu sendiri. Istilahnya, sumber daya yang dimiliki oleh suatu negara tersebut merupakan harta karun bagi negara tersebut. Dengan demikian dapat diartikan bahwa pengalokasian sumber daya yang baik tentu akan memberikan dampak baik bagi tata kelola dari pemerintahan yang baik pula.

6. Jelasnya tanggung jawab pemerintah yang harus diterapkan bagi negara yang ingin merealisasikan pemerintahan yang ideal ialah adanya kejelasan terkait tanggung jawab pemerintah. Jadi, ketika pemerintah telah melakukan suatu kinerja maka pemerintah harus sudi dikritik dan dievaluasi oleh masyarakat luas demi memperbaiki kinerja yang lalu. Sebagai contoh nyata adalah anggota Dewan Perwakilan Rakyat Daerah (DPRD). Sebagai dewan yang mengaku pilihan hati nurani rakyat, sudah sewajarnya mereka yang disebut sebagai dewan harus sudi menerima evaluasi, kritik dan aspirasi rakyat. Bukan lantas mempermainkan posisi yang mereka jabat saat ini demi kepentingan pribadi dan sekutunya saja tanpa adanya keberpihakan dengan rakyat itu sendiri.

7. Terdapat visi pembangunan yang luas yang harus diterapkan oleh suatu negara demi mewujudkan pemerintahan yang ideal ialah adanya visi pembangunan yang luas. Visi pembangunan yang luas 
tersebut maksudnya ialah sebuah visi yang sudah dipertimbangkan masakmasak dan mendalam demi mewujudkan tata kelola pemerintahan yang baik.

8. Tingginya orientasi terhadap tujuan bersama dalam upaya mewujudkan pemerintahan yang ideal dalam hal tata kelola pemerintahan ialah tingginya orientasi terhadap tujuan yang sama. Jadi, dengan adanya orientasi terhadap tujuan bersama yang tinggi bisa menyebabkan meningkatnya persatuan dan kesatuan seluruh masyarakat di negara Indonesia ini. Sejatinya dalam mewujudkan pemerintahan yang ideal, tiap-tiap masyarakat juga harus berperan serta dalam menyelenggarakan tata kelola pemerintahan yang baik.

Jadi, yang dimaksud dengan tata kelola dari pemerintahan yang baik tersebut merupakan suatu bentuk maupun wujud tanggung jawab yang meliputi wewenang administrasi, wewenang ekonomi hingga wewenang politik demi mengatur segala permasalahan sosial negara tersebut.

\section{SIMPULAN}

Berdasarkan pembahasan hasil penelitian fungsi pengawasan DPRD Dalam Mewujudkan Tata Kelola Pemerintahan yang baik. Adapun fungsi pengawasan DPRD adalah sebagai berikut.

1. Pengawasan DPRD Kota Depok melingkupi pengawasan terhadap pelaksanaan Perda dan peraturan perundang-undangan lainnya, peraturan Kepala Daerah, APBD, kebijakan pemerintah dalam melaksanakan program pembangunan daerah dan DPRD Kota Depok juga bertanggung jawab melakukan pengawasan terhadap layanan publik.

2. Karena DPRD berasal dari partai politik, maka faktor penghambat dalam pelaksanaan tugas DPRD termasuk fungsi pengawasan adalah sehubungan dewan selalu sibuk dalam mengurusi urusan partai politik, walaupun di atur dalam tata tertib bahwa tugas dewan harus diutamakan daripada urusan lain, namun pada kenyataannya dewan selalu mengutamakan urusan politik.

3. Sejatinya dalam mewujudkan pemerintahan yang baik, tiap-tiap masyarakat juga harus berperan serta dalam menyelenggarakan tata kelola pemerintahan yang baik. Jadi, yang dimaksud dengan tata kelola dari pemerintahan yang baik tersebut merupakan suatu bentuk maupun wujud tanggung jawab yang meliputi wewenang administrasi, wewenang ekonomi hingga wewenang politik demi mengatur segala permasalahan sosial daerah tersebut.

\section{SARAN}

Setelah disimpulkan dari hasil penelitian ini, maka perlu kiranya dibuat saran-saran untuk menjadi perhatian dalam menetapkan kebijaksanaan yang berhubungan dengan fungsi pengawasan DPRD Dalam Mewujudkan Tata Kelola Pemerintahan yang baik. Saran-saran tersebut adalah sebagai berikut.

1. Perlu adanya penguatan fungsi pengawasan DPRD Dalam Mewujudkan Tata Kelola Pemerintahan yang baik di Kota Depok Provinsi Jawa Barat, agar apa yang menjadi cita-cita daerah dapat terlaksana dengan baik berkaitan dengan penerapan Good Governance.

2. Mengenai Kendala-Kendala atau faktorfaktor yang penghambat dalam fungsi pengawasan DPRD Dalam Mewujudkan Tata Kelola Pemerintahan yang baik di Kota Depok Provinsi Jawa Barat, sebaiknya pemerintah memikirkan solusi bagaimana mengatasinya. Dengan demikian agenda untuk mewujudkan pemerintahan yang baik dan bersih dari KKN akan segera terlaksana. 
3. Upaya Revitalisasi Fungsi Pengawasan DPRD Dalam Mewujudkan Tata Kelola Pemerintahan yang baik di Kota Depok Provinsi Jawa Barat terus upayakan dilakukan guna meningkatkan pelayanan dan kinerja para wakil rakyat yang duduk di Kota Depok. Dan Prinsip yang harus diterapkan oleh Dewan adalah ditegakkannya supremasi hukum oleh DPRD Kota Depok.

\section{DAFTAR RUJUKAN}

George R. Terry, 1958 dalam bukunya Principles of Management (Sukarna, 2011: 10) membagi empat fungsi dasar manajemen, yaitu Planning (Perencanaan), Organizing (Pengorganisasian), Actuating (Pelaksanaan) dan Controlling (Pengawasan). Keempat fungsi manajemen ini disingkat dengan POAC.

Undang-Undang No. 17 Tahun 2014 tentang MPR, DPR, DPD dan DPRD adalah mitra sejajar dengan pemerintah daerah

UNDP mendefinisikan good governance adalah sebagai "the exercise of political economic, and administrative authority to manage a nations affair at all levels"
Dialektika ilmu pemerintahan penyunting: Dr. Muhadam Labolo, Dr. Hyronius Rowasiu, Dr. Megandaru Widhi Kawuryan. Penerbit GHALIA INDONESIA Jl. Rencananya Km.1 No. 47, Ciawi, Bogor 16720

Idrus, M. (2009). Metode penelitian Ilmu Sosial. Yogyakarta: Gelora Aksara Pratama

Creswell dalam kuswarno (2013: 47) , Mengemukakan tiga teknik utama pengumpulan data yang dapat digunakan dalam studi deskriptif kualitatif yaitu partisipan observasi, wawancara mendalam, dan dokumentasi

A.Michael Huberman, dan Matthew B. Miles. Analisis data kualitatif Terj. Tjejep Rohidi. Jakarta : UI Press, 1992.

Ahmadi, Rulam. 2016. Metodologi Penelitian Kualitatif. Yogyakarta: Ar-Ruzz Media

Hasil wawancara peneliti mengenai pengawasan DPRD Dalam Mewujudkan Tata Kelola Pemerintahan yang Baik dengan informan. 
Visioner ! Vol. $13 \backslash$ No. 3\Desember 2021 